\title{
MicroRNAs: tiny molecules with a significant role in mammalian follicular and oocyte development
}

\author{
Dawit Tesfaye ${ }^{1,2}$, Samuel Gebremedhn ${ }^{1,2}$, Dessie Salilew-Wondim ${ }^{1,2}$, Tsige Hailay ${ }^{1,2}$, \\ Michael Hoelker ${ }^{1,2}$, Christine Grosse-Brinkhaus ${ }^{1}$ and Karl Schellander ${ }^{1,2}$ \\ ${ }^{1}$ Institute of Animal Sciences, Department of Animal Breeding and Husbandry, University of Bonn, Bonn, Germany \\ and ${ }^{2}$ Center of Integrated Dairy Research, University of Bonn, Bonn, Germany \\ Correspondence should be addressed to D Tesfaye; Email: tesfaye@itw.uni-bonn.de
}

\begin{abstract}
The genetic regulation of female fertility (follicular development, oocyte maturation and early preimplantation embryo development) involves the spatio-temporal regulation of those genes that play key roles in various stages of the female reproductive axis.

MicroRNAs (miRNAs), a class of small non-coding RNAs, are known to regulate the expression of a large proportion of such genes. In recent decades, multiple studies have aimed to determine the roles of these non-coding RNAs in mammalian follicular development, oocyte growth and embryo development. These studies have applied a variety of approaches, including conditional knockout of miRNA biogenesis genes, high-throughput sequencing technologies for pattern recognition in miRNA expression and loss- and gain-of-function of miRNAs in various animal models. In addition to the cellular miRNAs, a large variety of RNAs are found in circulation, being coupled with extracellular vesicles, proteins and lipids. Because of their potential as diagnostic markers for abnormal physiologies, there is increasing interest in the identification of extracellular miRNAs in various biological fluids and spent in vitro culture media. This review focuses on studies addressing the expression and potential role of cellular and extracellular miRNAs in mammalian follicular cell physiology and subsequent ovarian functionality and oocyte maturation.

Reproduction (2018) 155 R121-R135
\end{abstract}

\section{Introduction}

The female fertility of mammalian species is a dynamic and well-coordinated process involving the proper function of several tissues and organs, including the hypothalamus, pituitary, ovaries and reproductive tract, which give rise to fertilizable gametes and support early embryo and fetal development. A suitable environment for successful fertilization and embryo development is achieved through regulated, spatio-temporal expression of multiple genes, involving both transcriptional and post-transcriptional (mRNA turnover, processing, storage and translation) regulations (Lim et al. 2003, Lasko 2011, Baranyai et al. 2015). RNA-binding proteins (RBPs) have long been suggested to be involved in the control of mRNA fate, and initial work had focused on the expression of RBPs in various stages of early embryo development (Bettegowda \& Smith 2007). However, the discovery of non-coding RNAs, including microRNAs (miRNAs), has revolutionized the study of post-transcriptional regulation.

The biogenesis of miRNAs is a complex process involving several classes of molecules regulating the transcription and processing of the primary miRNAs (pri-miRNAs) into mature and functional miRNAs. The first event in the activation of miRNAs is transcription from an miRNA gene, which is mediated by RNA polymerase II (Poll II) or, in some cases, RNA polymerase III (Pol III), to give rise to the pri-miRNA transcript (Lee et al. 2003, 2004). From that point onward, miRNA biogenesis can progress by either the canonical or non-canonical pathways. The canonical pathway involves the cleavage of pri-miRNA by a microprocessor complex of RNase II enzyme Drosha and the DiGeorge critical region 8 protein (DGCR8) and gives rise to a 60-70-nucleotide-long miRNA precursor (pre-miRNA) in the nucleus (Gregory et al. 2004). The non-canonical pathway skips the Droshamediated cleavage of pre-miRNA, and the premiRNA is instead generated through the splicing of introns from the mRNA transcript (Ruby et al. 2007). Following these nuclear processes, the pre-miRNAs are exported to the cytoplasm by Exportin-5 and Ran-GTP co-factor (Yi et al. 2003). Following this, the pre-miRNA is further cleaved by RNase III Dicer coupled with double-stranded TAR RNA-binding protein 2, which generates a 22-nucleotide-long miRNA duplex that binds with the Argonaute protein to be incorporated into the miRNA-induced silencing complex (miRISC) (Hutvagner et al. 2001, Hutvagner \& Zamore 2002). As shown in Fig. 1, miRISC recognizes 
binding sites within the $3^{\prime}$-UTR of the target mRNA, which leads to mRNA degradation or repression of protein translation.

Advances in library preparation and deep sequencing technologies have enabled the identification of several thousand miRNAs in various species, as deposited in the public database, namely miRbase (http://www. mirbase.org). However, the roles of miRNAs in various aspects of female fertility have mostly been evidenced by conditional deletion of the different miRNAprocessing machinery genes in mouse models (Fig. 1). The importance of canonical miRNA biogenesis for uterine development and fertility in female mice was demonstrated by conditional knockout (cKO) of DGCR8 using the progesterone receptor (PR)-Cre (DGCR ${ }^{\mathrm{d} / \mathrm{d}}$ ) (Kim et al. 2016); adult DGCR8 ${ }^{\mathrm{d} / \mathrm{d}}$ females do not have regular cycles and do not produce offspring. However, normal ovulation could be induced in these mice by administering exogenous gonadotropins. The dicer $\mathrm{KO}$ model has been widely used to study the role of miRNAs in female reproduction (Bernstein et al. 2003, Murchison et al. 2007, Hong et al. 2008, Nagaraja et al. 2008, Luense et al. 2009, Mattiske et al. 2009, Lei et al. 2010). Dicer is abundant in almost all organisms, suggesting its evolutionary conservation. Dicer is involved in miRNA biogenesis (both canonical and noncanonical pathways for both miRNAs and other small RNAs in mammals) (Ha \& Kim 2014). cKO experiments involving the dicer and DGCR8 genes have revealed the involvement of canonical and non-canonical miRNA pathways in the proper function of the reproductive system in female mice.

While the majority of the miRNAs identified so far are intra-cellular, a tremendous number of miRNAs have been reported to circulate in the extracellular environment in almost all biological fluids, which are referred to as extracellular miRNAs. These extracellular miRNAs are found coupled with extracellular vesicles, high-density lipoproteins and Argonaute (AGO) proteins. Because of their stability under extreme environmental conditions, extracellular miRNAs have the potential as biomarkers for various biological processes, including disease detection and prediction of the developmental competence of oocytes and embryos.

Here we review the literature addressing the role of cellular and extracellular miRNAs in mammalian fertility associated with follicular development, ovarian granulosa cell function, oocyte growth and development.

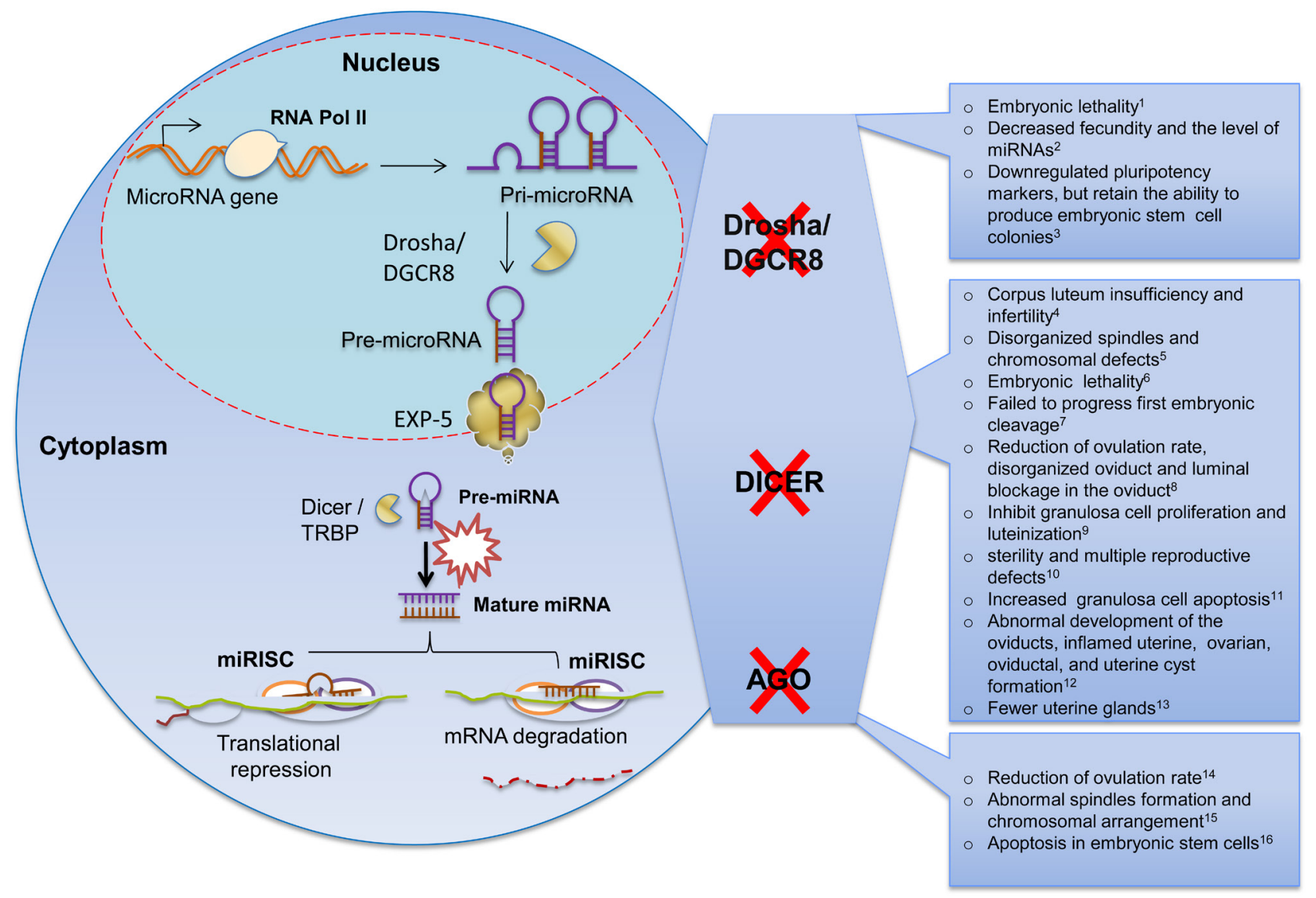

Figure 1 The microRNA biogenesis pathways and selective knockout of key miRNA machinery genes and the associated phenotypic effects on mammalian female fertility. 


\section{miRNAs in various stages of mammalian follicular development}

Mammalian follicular development is a highly coordinated and accurately regulated physiological process, which starts with the periodic recruitment of small growing follicles from the primordial follicle reserve, followed by selection of a few follicles for further maturation and dominance that result in ovulation of a developmentally competent oocyte (Fortune 1994, Fortune et al. 2000). Thus, the mammalian ovary is a dynamic organ in which a series of tissue remodeling and inflammatory reactions takes place to allow the release of a fertilizable oocyte (Espey 1980, 1994). Follicular recruitment, selection, dominance and ovulation are tightly regulated (Imbar \& Eisenberg 2014). Since their discovery as molecular regulators responsible for timedependent developmental events (Lee et al. 1993, Wightman et al. 1993), miRNAs have emerged as key post-transcriptional regulatory RNA molecules.

\section{miRNAs in ovarian development and activation of primordial follicles}

miRNAs are expressed in almost all mammalian tissues, including the ovarian tissues of humans (Liang et al. 2007), mice (Ro et al. 2007, Ahn et al. 2010), cows (Hossain et al. 2009), goats (Ling et al. 2014), sheep (Di et al. 2014) and pigs (Li et al. 2011). Following the successful development of Dicer1 KO mice models (Hong et al. 2008, Otsuka et al. 2008, Nagaraja et al. 2008, Luense et al. 2009), multiple studies have reported the involvement of miRNAs in primordial follicle activation and maintenance. A study by Xu et al. (2011a) identified the proliferating cell nuclear antigen (PCNA) as a key gene involved in follicular assembly. RNA interference (RNAi) knockdown of PCNA in the neonatal mouse ovary reduced oocyte apoptosis and increased primordial follicle assembly by downregulating proapoptotic genes (BAX, TNF and TNFR-2). Following this, post-transcriptional regulation of PCNA by miR-376a in neonatal mouse primordial follicles was reported by Zhang et al. (2014). In the same study, overexpression of miR-376a in cultured mouse ovaries increased the number of primordial follicles and decreased oocyte apoptosis, as observed in ovaries transfected with short interfering (siRNA) that selectively targeted PCNA. The involvement of miRNAs in promoting primordial follicle initiation was further substantiated by the enrichment of miR-145 in the neonatal mouse ovary, which alters the expression of zona pellucida sperm-binding protein genes and activates the transforming growth factor (TGF)- $\beta$ signaling pathway (Yang et al. 2013). Also, an inhibitory effect of miRNAs on primordial follicle formation has been reported in which miR-143 was selectively enriched in mouse pre-granulosa cells, thereby suppressing genes related to cell proliferation and cell cycle (Zhang et al. 2013a).

\section{miRNAs during early luteal phase and follicular selection and dominance}

As follicles grow in size, the layers of granulosa cells encircling the oocyte increase in number (Braw-Tal \& Yossefi 1997) and follicle size variability becomes evident due to the onset of deviation (Ginther et al. 1997). Because of this variability, clear differences were observed in the transcriptome profile of granulosa cells derived from small and large follicles (Hatzirodos et al. 2014b). With this rationale, Sontakke et al. (2014) performed an expression analysis of miRNAs in follicles of variable size and health status and identified an association with follicular selection and dominance. MiR-144, miR-202 and miR-873 were upregulated in large healthy follicles compared to large atretic counterparts. In an attempt to elucidate the involvement of miRNAs in the bovine early luteal phase of the estrous cycle, the expression signature of miRNAs was assessed in granulosa cells of dominant and subordinate follicles derived from days 3 and 7 of the estrous cycle (Salilew-Wondim et al. 2014). Here, no difference was observed between early stage (day 3 of the estrous cycle) dominant and subordinate follicles compared to the mid-stage follicles (day 7 of the estrous cycle). This was further observed in the principal component analysis (PCA), which showed no clear separation between dominant and subordinate follicles from day 3 of the estrous cycle. However, dominant and subordinate follicles from the mid-luteal phase showed a clear clustering pattern due to differences in granulosa cell miRNA expression profiles at day 7 of the estrous cycle (Fig. 2). This phenomenon was also observed at the mRNA transcriptome level, where smaller antral follicles tend to be heterogeneous compared to the larger antral follicles (Hatzirodos et al. 2014b).

\section{Involvement of miRNAs during the preovulatory stage of follicular development}

Understanding the involvement of miRNAs in the later stages of the estrous cycle (follicular phase) could provide useful information on the regulatory mechanisms associated with the luteinization of granulosa cells and ovulation of the preovulatory and degradation of the remaining follicles. Differential expression of miRNAs between dominant vs subordinate and dominant vs luteinized follicles in equine suggests the involvement of miRNAs in follicular selection and ovulation (Schauer et al. 2013). Similarly, a significant difference in the expression pattern of miRNAs was observed in granulosa cells of preovulatory dominant and subordinate follicles derived from day 19 of the bovine estrous cycle (Gebremedhn et al. 2015). In that 


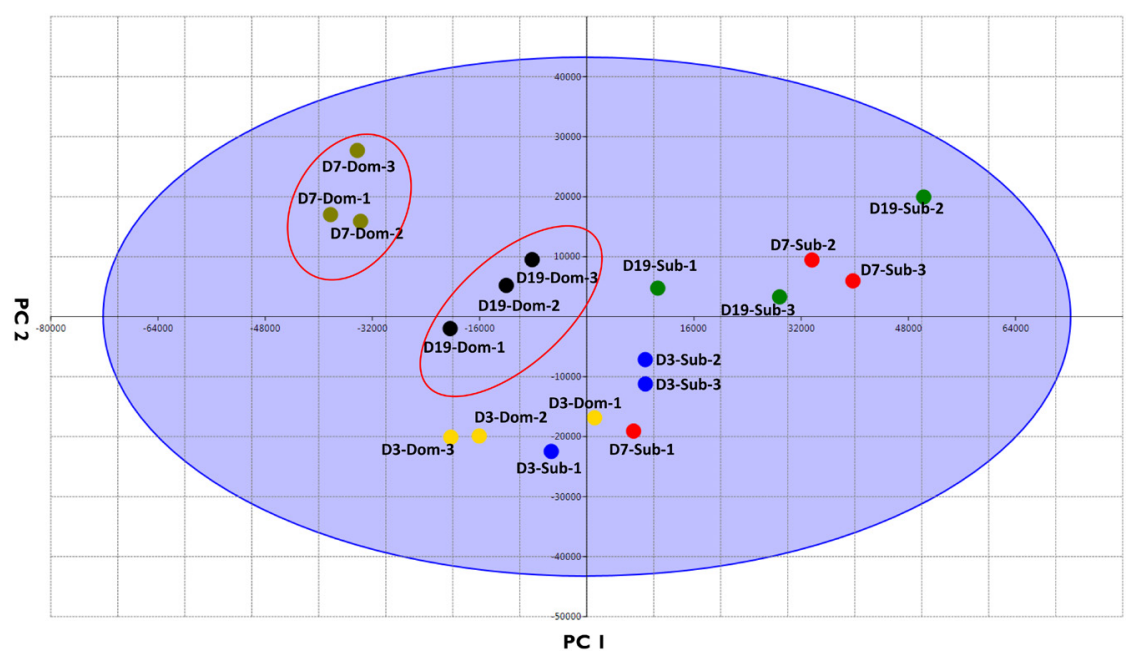

Figure 2 Principal component analysis (PCA) of normalized miRNA expression data derived from granulosa cells of dominant and subordinate follicles from early luteal (days 3 and 7) and late follicular (day 19) phases of the estrous cycle. Each rounded color represents a replicate of the individual follicular category. The dominant follicles of days 7 and 19 are clearly separated from the remaining follicular categories. The normalized miRNA expression data were obtained from Salilew-Wondim et al. (2014) and Gebremedhn et al. (2015). study, the PCA analysis identified a clear separation of the two follicle populations (Fig. 2). Further in silico analysis of the differentially expressed miRNAs, which aimed to characterize the genomic context, revealed an interesting pattern of co-enrichment and repression of specific miRNA clusters. For instance, miR-21 and three miRNA clusters (miR-183-96-182, miR-132-212 and miR-424-450-542) were preferentially enriched in granulosa cells of preovulatory dominant follicles. This could be because these clusters of miRNAs are involved in rescuing granulosa cells of the preovulatory dominant follicles from undergoing apoptosis, as has been described in bovine (Gebremedhn et al. 2016) and other species (Carletti et al. 2010).

\section{The dynamics of cellular miRNAs during the estrous cycle}

The focus of the majority of the miRNA expression analysis studies has been to identify those miRNAs that are differentially expressed between follicular categories. Nonetheless, determining the highly abundant miRNAs commonly expressed in all follicular categories could shed light on the role of miRNAs in maintaining normal physiological processes of follicular development. For instance, in the above-mentioned studies, among the 20 highly abundant miRNAs, 15 (bta-miR-10b, bta-miR-26a, bta-miR-99b, bta-miR-27b, bta-let-7f, bta-let-7a-5p, bta-let-7i, bta-miR-92a, bta-miR-191, btamiR-125a, bta-miR-148a, bta-miR-186, bta-miR-143, bta-miR-30d and bta-miR-30a-5p) are expressed irrespective of the follicular categories (SalilewWondim et al. 2014, Gebremedhn et al. 2015). These miRNAs were also reported to be abundantly expressed in ovarian tissues of cow (Hossain et al. 2009), goat (Zhang et al. 2013c, An et al. 2016), pig (Huang et al. 2016a) and other mammalian species, suggesting a housekeeping role for these miRNAs in maintaining the normal physiological processes in mammalian female reproduction (Zi et al. 2017).
The molecular mechanisms underlying follicular growth, onset of deviation and atresia were assessed by studying the dynamics of gene transcripts in granulosa cells throughout the bovine estrous cycle (Hatzirodos et al. 2014a,b, Li et al. 2016). Thus, identifying the expression trends of miRNAs in mammalian granulosa cells at different time points of the estrous cycle would likely provide insights into the post-transcriptional gene regulatory mechanisms that orchestrate follicular development. To address this, a meta-analysis was performed on previously generated miRNA expression datasets from dominant and subordinate follicles of days 3, 7 (Salilew-Wondim et al. 2014) (GOE accession number: GSE55987) and 19 (Gebremedhn et al. 2015) (GOE accession number: GSE56002) of the bovine estrous cycle. The least square mean for time and type of follicles and a linear regression model for days 3 and 7 and days 7 and 19 were estimated. Finally, the slope and intercept of the trends generated were used to characterize and cluster miRNAs. Based on the sign of the slope between the two time points, four categories $\left({ }^{\prime}+,+^{\prime},{ }^{\prime}+,{ }^{\prime}{ }^{\prime},{ }^{\prime}-,{ }^{\prime}\right.$ ' and $\left.{ }^{-}-,-{ }^{\prime}\right)$ were identified. For example, $'+,+{ }^{\prime}$ indicated miRNAs with an increasing trend between days 3 and 7 and days 7 and 19. The genomic contexts of miRNAs in the dominant follicles of each category revealed an interesting pattern, and representative miRNA clusters that belong to each category are indicated in Fig. 3 . For example, the miR-132-212 and miR-183-96-182 clusters (transcribed from chromosomes 19 and 4 of the bovine genome, respectively) are included in the ',++ ' category, which might be associated with their potential role in promoting survival of granulosa cells in the dominant follicles during the later stages of the estrous cycle. This was validated by a loss-and-gain-of-function experiment in which overexpression of the miRNA cluster promoted cell proliferation and $\mathrm{G}_{1} / \mathrm{S}$ cell cycle transition by coordinately targeting the pro-apoptotic FOXO1 transcription factor and its pro-apoptotic downstream transcript, FASL (Gebremedhn et al. 
2016). Similarly, the miR-132-212 cluster miRNAs are associated with ovulation and are elevated after the induction of an ovulatory dose of luteinizing hormone (LH)/human chorionic gonadotropin (hCG) (Fiedler et al. 2008), preventing cells from entering into apoptosis. On the other hand, miRNA clusters, including miR-23a27a-24, miR-222-221 and miR-214-199a (transcribed from chromosomes $7, \mathrm{X}$ and 16 of the bovine genome, respectively), showed increasing expression until the mid-luteal phase but decreasing expression in the dominant follicle granulosa cells during the later follicular phase of the estrous cycle (Fig. 3). MiR-23a and miR-27a have been reported to promote granulosa cell apoptosis by targeting SMAD5 through the FasL-Fasmediated pathway (Nie et al. 2015). This would support the notion that miRNAs are involved in the induction of apoptosis in subordinate follicles, thereby facilitating their destination to atresia.

\section{Functional role of miRNAs in granulosa cells}

The proliferation, differentiation and steroidogenic functions of granulosa cells are necessary for key events throughout mammalian follicular development, including recruitment, selection and dominance of follicles and atresia of anovulatory subordinate follicles. The significant role of Dicer in mammalian folliculogenesis has been evidenced using a tissuespecific deletion of Dicer in granulosa cells (Lei et al. 2010). In that study, age-specific investigation of

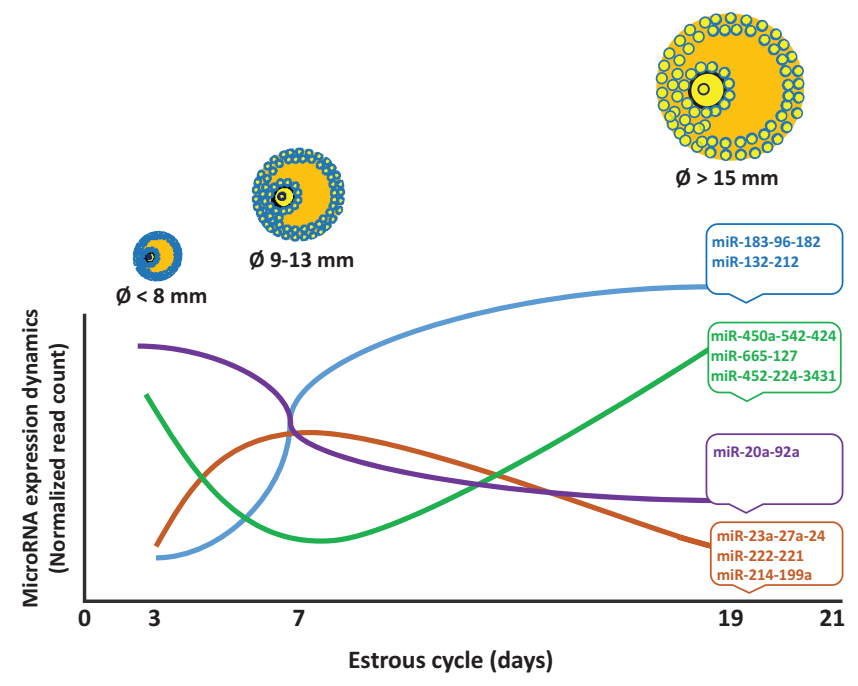

Figure 3 Temporal miRNA expression dynamics in granulosa cells of dominant follicles during the estrous cycle. The diameter $(\varnothing)$ of the dominant follicles increases as the estrous cycle progresses. Representative miRNA clusters belonging to each of the expression dynamics pattern are indicated with different colors. The $X$ - and $Y$-axes represent the days of the estrous cycle and normalized miRNA expression values, respectively. The analysis was carried out based on the published data from Salilew-Wondim et al. (2014) and Gebremedhn et al. (2015). mice ovaries with inactivated Dicer in granulosa cells revealed increased primordial follicle pool endowment, accelerated early follicle recruitment and more degenerate follicles in the cKO ovaries compared to the wild-type counterpart. Although normal ovulation could occur in mice with disrupted dicer in granulosa cells, impaired oocyte development is a known cause of infertility (Nagaraja et al. 2008, Gonzalez \& Behringer 2009) in those models. Moreover, the defective miRNA pathway in granulosa cells and subsequent effects on oocyte development have been evidenced by a histological analysis of dicer cKO ovaries, showing a higher number of degenerated follicles and impaired oocyte development (Lei et al. 2010).

Granulosa cells are relatively easy to isolate and maintain under an in vitro cell culture system and, therefore, are a widely studied ovarian cell type. Several molecular genetics studies have used granulosa cells as a model. Granulosa cells are often used in in vitro loss- and gain-of-function studies to investigate the role of individual (or clusters of) miRNAs. A large body of studies are available evidencing the regulatory role of miRNAs in granulosa cell proliferation (Sirotkin et al. 2010, Yao et al. 2010a, Yan et al. 2012, Andreas et al. 2016, Gebremedhn et al. 2016), survival (Carletti et al. 2010, Lin et al. 2012, Yang et al. 2012, Sirotkin et al. 2014, Gebremedhn et al. 2016), terminal differentiation (Kitahara et al. 2013, Andreas et al. 2016) and steroidogenesis (Sirotkin et al. 2009, Xu et al. 2011b, Yin et al. 2012, Dai et al. 2013). Table 1 summarizes the functionally validated miRNAs of various ovarian tissues, including granulosa and cumulus cells and oocytes.

The proliferation of granulosa cells plays a crucial role in creating a unique microenvironment that nurtures the growing oocyte (Maruo 1995). Extra- and intra-ovarian factors have been reported to regulate follicular development, including TGF- $\beta$ superfamily members and SMADs (Miyazawa et al. 2002, van den Hurk \& Zhao 2005). Several members of the TGF- $\beta$ superfamily are implicated in granulosa cell proliferation (Hsueh et al. 1984, Hirshfield 1991). The conserved housekeeping miR-10 family (miR-10a and miR-10b) is expressed at basal levels in granulosa cells. MiR-10 family members have been shown to slow the rate of granulosa cell proliferation and induce apoptosis in human, mouse and rat granulosa cells by suppressing key genes (TGF $\beta 1$, Activin A, BMP4 and BMP15) in the TGF- $\beta$ pathway (Jiajie et al. 2017). This suggests the existence of a negative feedback loop between miRNAs and TGF- $\beta$ pathway. Involvement of miR-15a in the regulation of human granulosa cell proliferation was evaluated by transfecting primary granulosa cells with antisense constructs capable of inhibiting miR-15a, which resulted in increased expression of cell proliferation marker genes (MAPK/ERK1, 2 and PCNA), whereas overexpression of miR-15a leads to an 
Table 1 Summary of the role miRNAs in different reproductive tissues of various mammalian species.

\begin{tabular}{|c|c|c|c|c|}
\hline $\begin{array}{l}\text { Biological tissue/ } \\
\text { cells/fluid }\end{array}$ & miRNAs & $\begin{array}{l}\text { Associated biological } \\
\text { functions }\end{array}$ & Species & References \\
\hline Granulosa cells & 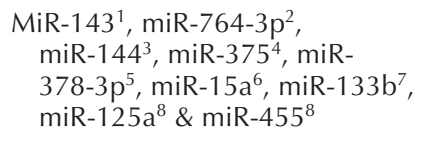 & $\begin{array}{l}\text { Regulation of steroid } \\
\text { synthesis }\end{array}$ & $\mathrm{M}^{1,2,3,7}, \mathrm{P}^{4,5}, \mathrm{H}^{6}, \mathrm{R}^{8}$ & $\begin{array}{l}\text { 1Zhang et al. (2017), }{ }^{2} \text { Wang et al. } \\
\text { (2016), }{ }^{3} \text { Zhou et al. (2017), }{ }^{4} \mathrm{Yu} \\
\text { et al. (2016), }{ }^{5} \text { Toms et al. (2015), } \\
{ }^{6} \text { Sirotkin et al. (2014), }{ }^{7} \text { Dai et al. } \\
\text { (2013), }{ }^{8} \text { Hu et al. (2012) }\end{array}$ \\
\hline Granulosa cells & 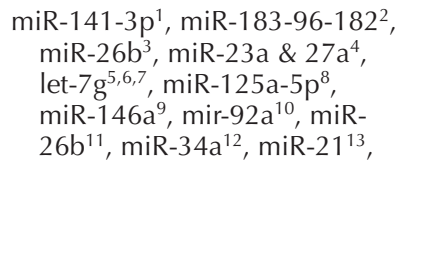 & $\begin{array}{l}\text { Regulation of granulosa } \\
\text { cell apoptosis }\end{array}$ & $\begin{array}{l}R^{1}, B^{2}, P^{3,7,10,11,12} \\
H^{4,5,6,9}, M^{8,13}\end{array}$ & $\begin{array}{l}{ }^{1} \mathrm{Li} \text { et al. }(2017),{ }^{2} \mathrm{Gebremedhn} \text { et al. } \\
\text { (2016), }{ }^{3} \mathrm{Liu} \text { et al. (2016), }{ }^{4} \mathrm{Nie} \\
\text { et al. (2015), }{ }^{5} \mathrm{Cao} \text { et al. (2015), } \\
{ }^{6} \mathrm{Zhou} \text { et al. (2017), }{ }^{7} \mathrm{CaO} \text { et al. } \\
(2015),{ }^{8} \mathrm{Wang} \text { et al. (2016), }{ }^{9} \mathrm{Chen} \\
\text { et al. (2015), }{ }^{10} \text { Liu et al. (2014), } \\
{ }^{11} \text { Lin et al. (2012), }{ }^{12} \mathrm{Tu} \text { et al. } \\
\text { (2014), }{ }^{13} \text { Carletti et al. (2010) }\end{array}$ \\
\hline Granulosa cells & 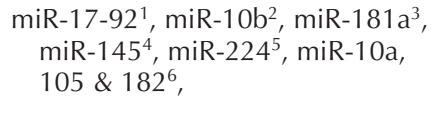 & $\begin{array}{l}\text { Regulation of granulosa } \\
\text { cell proliferation and } \\
\text { differentiation }\end{array}$ & $\mathrm{B}^{1}, \mathrm{G}^{2}, \mathrm{M}^{3,4,5}, \mathrm{H}^{6}$ & $\begin{array}{l}{ }^{1} \text { Andreas et al. (2016), }{ }^{2} \text { Peng et al. } \\
\text { (2016), }{ }^{3} \text { Zhang et al. (2013b), } \\
{ }^{4} \text { Yan et al. (2012), }{ }^{5} \text { Yao et al. } \\
\text { (2010a), }{ }^{6} \text { Sirotkin et al. (2010) }\end{array}$ \\
\hline Cumulus cells & $\begin{array}{l}\text { miR-378 }{ }^{1}, \text { miR-2242 } \\
\quad \text { miR-509-3 } 3 p^{4}\end{array}$ & $\begin{array}{l}\text { Regulate oocyte } \\
\text { maturation, embryo } \\
\text { development and } \\
\text { estradiol secretion }\end{array}$ & $\mathrm{P}^{1,2}, \mathrm{H}^{3}$ & $\begin{array}{l}{ }^{1} \text { Pan et al. (2015), }{ }^{2} \text { Li et al. (2017), } \\
{ }^{3} \text { Karakaya et al. (2015), }{ }^{4} \text { Huang } \\
\text { et al. (2016b) }\end{array}$ \\
\hline Oocytes and embryos & 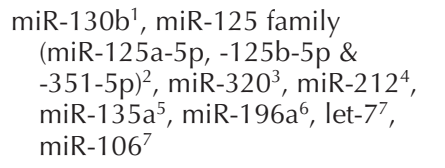 & $\begin{array}{l}\text { Regulation of oocyte } \\
\text { maturation or early } \\
\text { embryo development } \\
\text { (maternal embryo } \\
\text { genome transition) }\end{array}$ & $B^{1,4,6,7}, M^{2,3,5}$ & $\begin{array}{l}{ }^{1} \text { Sinha et al. (2017), }{ }^{2} \text { Kim et al. } \\
\text { (2016), }{ }^{3} \text { Feng et al. (2015), } \\
{ }^{4} \text { Tripurani et al. (2013), }{ }^{5} \text { Pang } \\
\text { et al. (2011), }{ }^{6} \text { Tripurani et al. } \\
\text { (2011), }{ }^{7} \text { Miles et al. (2012) }\end{array}$ \\
\hline Follicular fluid & 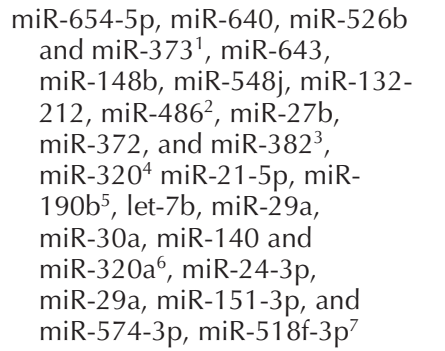 & $\begin{array}{l}\text { Indicators of oocyte } \\
\text { developmental } \\
\text { competence, antral } \\
\text { follicle development, } \\
\text { follicular maturation }\end{array}$ & $\mathrm{B}^{1,2,3}, \mathrm{MR}^{4}, \mathrm{H}^{5,6,7,8}$ & $\begin{array}{l}{ }^{1} \text { Sohel et al. (2013), }{ }^{2} \text { Navakanitwor- } \\
\text { akul et al. (2016), }{ }^{3} \text { da Silveira } \\
\text { et al. (2014), }{ }^{4} \text { Feng et al. (2015), } \\
{ }^{5} \text { Diez-Fraile et al. (2014), }{ }^{6} \text { Scalici } \\
\text { et al. (2016), }{ }^{7} \text { Sørensen et al. } \\
\text { (2016) }\end{array}$ \\
\hline
\end{tabular}

B, Bovine; G, Goat; M, mouse; MR, Mare P, pig; R, Rat.

inhibition of these marker genes (Sirotkin et al. 2014). The proliferation marker genes PCNA and cyclin D2 have also been reported to be downregulated by the overexpression of miR-181a, which, in turn, suppresses the expression of activin receptor IIA (acvr2a), thereby slowing the rate of granulosa cell proliferation (Zhang et al. 2013b). Induction of TGF- $\beta 1$-dependent granulosa cell proliferation was observed upon overexpression of miR-224 by regulating the expression of SMAD4 (Yao et al. 2010a).

It is well known that the majority of the ovarian follicles recruited during follicular development undergo atresia, which is triggered by granulosa cell apoptosis (Hughes \& Gorospe 1991). There is accumulating evidence suggesting a role of miRNAs in regulating apoptosis of granulosa cells and determining follicular fates. miR-21 is enriched in murine granulosa cells upon induction of an ovulatory dose of LH (Carletti et al. 2010). In the same study, the anti-apoptotic role of miR-21 was verified by an increased abundance of caspase positive cells (an indicator of apoptosis) in the ovarian cortex upon inhibition of miR-21, which resulted in a reduced rate of ovulation. Similarly, miR-92a prevents porcine granulosa cell apoptosis by targeting the SMAD7 gene (Liu et al. 2014). This shows that miR-92a prevents TGF$\beta$-induced apoptosis in granulosa cells by fine-tuning the expression of SMAD7. In a similar study, the enrichment of the miR-183-96-182 cluster in granulosa cells of preovulatory dominant follicle was associated with a downregulation of the pro-apoptotic gene FASL, which has been shown to regulate granulosa cell apoptosis in a FOXO-dependent manner (Gebremedhn et al. 2016). The expression of Bax and other pro-apoptotic genes was significantly reduced in human granulosa cells due to overexpression of miR-22 (Sirotkin et al. 2010). In a separate experiment, it was confirmed that the expression of miR-22 in mice granulosa cells progressively declined as follicles shifted from healthy to atretic follicles, and with a regulatory effect on SIRT1 (Xiong et al. 2016a).

In an attempt to determine the effect of miRNAs on ovarian cell steroidogenesis, a genome-wide screening 
experiment was performed in human in vitro cultured granulosa cells through transfection of 80 different human pre-miRNA constructs. It was shown that 36 miRNA constructs resulted in inhibition of progesterone release, while 10 miRNAs promoted the release of progesterone from granulosa cells (Sirotkin et al. 2009). In the same study, the release of estradiol was suppressed by 51 miRNAs, although none of the miRNA precursors stimulated estradiol synthesis. Overexpression of miR-378 in cultured murine granulosa cells downregulated transcription of the PR gene and its downstream transcripts; ADAMTS1, CTSL1 and PPARG (Toms et al. 2015). In a separate study, miR-378 suppressed aromatase protein expression and, thereby, estradiol production in porcine granulosa cells (Xu et al. 2011b). The release of estradiol from human and murine granulosa cells was inhibited upon overexpression of miR-34a and miR-320, respectively (Sirotkin et al. 2009, Yin et al. 2014). Estradiol synthesis in mouse granulosa cells was shown to be impaired by the overexpression of miR-764-3p, which suppresses the steroidogenic factor-1 (SF-1) (Wang et al. 2016). In the same study, it was reported that miR-764-3p-mediated repression of SF-1 leads to the suppression CYP19A1, which is a downstream target gene of SF-1. Contrary to this, miRNAs are reported to positively affect estradiol production in granulosa cells. A direct link between FoxL2 and miR-133b was reported, and miR-133b was shown to induce estradiol production by inhibiting the FoxL2 binding sites that target the promoter sequences of StAR and CYP19A1 (Dai et al. 2013). Moreover, miR-132 promotes estradiol production in mouse granulosa cells via translational repression of Nurr1 in the CAMP signaling pathway, which induces the expression of CYP19Al (Wu et al. 2015). Similarly, miR383 has been reported to positively regulate estradiol production by inhibiting RBMS1 and inactivating C-MYC (Yin et al. 2014).

miRNAs are not only involved in regulating mammalian steroidogenesis, but their expression is also affected by the level and composition of steroids in the follicular environment (Donadeu et al. 2016). In 2008, a report by Fiedler et al. (2008) demonstrated that treatment of preovulatory mouse mural granulosa cells with hCGs leads to differential expression of 13 miRNAs, and miR-132 and miR-212 were found to be highly upregulated post-hCG treatment. In line with this, hyperstimulation of cyclic heifers with supraphysiological levels of FSH induced changes in the expression of circulating miRNAs of follicular fluid and blood plasma, which could have an association with oocyte development (Noferesti et al. 2015). Similarly, treatment of cultured granulosa cells with $\mathrm{FSH}$ leads to changes in the expression of a large set of miRNAs, of which miR-29a and miR-30d were suppressed in the short term but upregulated in the long term (Yao et al. 2010b).

\section{The expression and role of miRNAs during oocyte maturation}

Oocyte maturation is the process by which the oocyte undergoes a morphological, physiological and developmental transformation from the prophase I to metaphase II (MII) stage by sequential meiotic division, chromatin remodeling and cytoplasmic organelle reorganization (Eppig 1996). While the oocyte progresses in growth and development, it acquires maternal stores (mRNAs and proteins) which are essential to support the development of the embryo during the early cleavage stages (Li et al. 2010). Global gene expression studies have shown that while about 400 genes are differentially expressed between immature and mature porcine oocytes (Budna et al. 2017), as many as 821 gene transcripts can be differentially regulated during the bovine oocyte maturation (Fair et al. 2007). Therefore, understanding the mechanisms by which the protein and mRNA are dramatically accumulated or degraded during the different stages of oocyte maturation is the main research focus in the field of female gametogenesis.

In animals, three main classes of small RNAs (miRNAs, siRNA and PIWI-interacting RNAs) are known to posttranscriptionally regulate gene expression through interactions with AGO proteins. Germ-cell-specific dicer knockout models have been used to demonstrate the significant role of Dicer in oocyte meiotic maturation by affecting spindle formation and chromosomal organization (Murchison et al. 2007). Similar results were also obtained when the expression of Dicer was depleted using RNAi (Liu et al. 2010). Moreover, in mouse oocytes, functional loss of Argonaute 2 (AGO2), which plays a key role in miRNA biogenesis (Diederichs \& Haber 2007), caused spindle formation defects and chromosomal arrangement abnormalities, as well as the downregulation of several miRNAs, including let-7a, -b, -c, -d, -f, -g and -7i (Kaneda et al. 2009). The expression of genes involved in the RNA microprocessor (RNASEN, DGCR8 and Dicer1), miRNA transportation (RANGAP1, XPO1, XPO4 and XPO5) and components of the RNAinducing silencing complex (EIF2C1, EIF2C2 and EIF2C3) in immature and mature rhesus monkey oocytes is also an indirect indicator of the presence of mature miRNAs during oocyte maturation (Mtango et al. 2009). Furthermore, increasing the level of Drosha, the RNase III which is essential for the first step of miRNA processing in the nucleus (Lee et al. 2003), was associated with increased pri-miRNA-processing activity in Xenopus oocytes, suggesting the presence of active miRNA biogenesis during oocyte maturation in that species (Muggenhumer et al. 2014). Nevertheless, Suh et al. (2010) have argued that functional loss of DGCR8 in the mouse oocytes does not affect oocyte maturation and embryo development, despite the significant effect on the miRNA biogenesis, thus suggesting that miRNAs might not be involved in oocyte maturation and embryo 
development. Similarly, unlike for Dicer, depletion of Drosha or DGCR8 during porcine oocyte maturation did not affect the maturate rate (Liu et al. 2017b). Because Dicer is involved in both RNAi and miRNA biogenesis pathways, Suh et al. (2010) claimed (based on Dicer knockout/knockdown models) that the endogenous small interfering pathway is more important than the miRNAs during oocyte maturation. Nevertheless, apart from the canonical pathways, which involves DGCR8, Drosha, Dicer, Argonaute 2 and miRNA-processing genes, evidence indicates that miRNAs are also generated by the non-canonical pathway, which does not involve DGCR8, Dicer, Drosha or Argonaute 2 (Havens et al. 2012, Castellano \& Stebbing 2013). Therefore, rather than relying on miRNA-processing genes, miRNAspecific knockout/knockdown experiments can be used as an alternative approach to address the roles of miRNAs during mammalian oocyte maturation and subsequent embryo development.

In line with this, specific and global miRNA profiling studies have indicated that changes in the expression pattern of biologically relevant miRNAs occur during the growth and development of mammalian oocytes (Tesfaye et al. 2009, Xu et al. 2011c, Xiong et al. 2016b). For example, miR-21, an miRNA whose target genes potentially participate in fatty acid metabolism and fatty acid biosynthesis, was found to be differentially expressed during oocyte maturation (Song et al. 2016). Interestingly, inhibition of miR-21 using an anti-miR21 peptide nucleic acid resulted in a reduced proportion of porcine oocytes reaching the MII stage and further embryo development (Wright et al. 2016). Similar results were also obtained by inhibiting the activity of let-7c, miR-27a and miR-322 in mouse oocytes (Kim etal. 2013), miR-15/16 in Xenopus oocytes (Wilczynska et al. 2016) and miR-378 in the porcine oocyte (Pan et al. 2015). On the other hand, increasing the expression of miR-224 in cumulus cells reduced the oocyte maturation rate and blastocyst development by regulating PTX3 expression (Li et al. 2017). More recently, it was shown that inhibition of miR-130b activity during bovine oocyte in vitro maturation reduced the first polar body extrusion, the proportion of oocytes reaching to MII stage and mitochondrial activity in the MII oocytes, indicating the involvement of this miRNA in bovine oocyte maturation (Sinha et al. 2017).

Under in vitro conditions, the dynamic miRNA profile changes are partly attributed to the in vitro maturation environment or ingredients used, while under in vivo conditions, the miRNA profile could be affected by the physiological conditions like the age of the animal. For example, in humans, treatment of metaphase I (MI) human oocytes with insulin-like growth factor 1 activates the expression of miR-133a, miR-205-5p and 145 miRNAs and suppresses 200 others, including miR152 and miR-142-5p (Xiao et al. 2014). On the other hand, altered expression of 12 miRNAs (including let-
$7 b-5 p$ and let-7e-5p) in oocytes derived from older woman compared to young women suggests that the in vivo miRNA profile in the oocytes is affected by oocyte aging (Battaglia et al. 2016). However, further functional studies are required to gain better insight into the role of those miRNAs whose expression is altered due to suboptimal culture conditions or aging.

The earliest stages of embryogenesis are dependent on the maternal store of transcripts and proteins, which decay during development so that embryonic development becomes dependent on transcripts and proteins from the embryonic genome (Telford et al. 1990). This maternal-zygotic transition occurs at the one-two cell stage in mice (Schultz 1993), 4-8 cell stage in humans (Telford et al. 1990) and 8-16 cell stage in bovine, with minor transcription at a zygote and 2-cell stages (Memili \& First 1999). Like mRNA transcripts, oocytes are also known to be equipped with a large set of maternal miRNAs which are utilized or inherited by the embryo after fertilization and play a significant role in further development (Tang et al. 2007). In mice, a large-scale miRNA expression analysis comparing growing and matured oocytes and zygote stage embryos revealed dynamic changes in miRNA expression during oogenesis, whereas matured oocytes and zygotes had similar expression profiles, indicating significant maternal miRNA inheritance before the first cleave and divisions (Tang et al. 2007). In the same study, a significant number of these miRNAs $(60 \%)$ were degraded at the one-two cell stages, suggesting that a significant proportion of the maternally inherited miRNAs are actively degraded during the first cell division. Maternally stored miRNAs might regulate embryonic genome activation and maternal mRNA degradation. This has been evidenced in zebrafish in which zygotic miR-430 targets several maternal mRNAs by accelerating the deadenylation and clearance of maternal mRNAs during early embryonic stages (Giraldez et al. 2006). Bovine expression profile studies have revealed that miRNAs are expressed in a stage-specific manner during embryo preimplantation following a typical maternal or embryonic pattern (Mondou et al. 2012, Abd El Naby et al. 2013).

\section{miRNAs associated with ovarian pathophysiology}

The malfunctioning of the ovary due to physiological, endocrine, paracrine or metabolic disorders can result in female infertility. During this time, the expression of some miRNAs could be induced or repressed by the normal ovarian physiology, ultimately leading to the termination of ovarian folliculogenesis. Identification and an in-depth understanding of these dysregulated miRNAs due to the ovarian disorder might identify appropriate molecular strategies to protect against ovarian disorders. For example, miR-18a is believed to be involved in the development of ovarian cancer by inducing cell cycle arrest and enhancing apoptosis by regulating the 
expression of the inositol phosphate multikinase gene (Liu et al. 2017a) Likewise, while miR-30d suppresses ovarian cancer progression by inhibiting TGF- $\beta 1$ induced epithelial-mesenchymal transition (Ye et al. 2015), overexpression of miR-1271, miR-223-3p and miR-761 induces the development of ovarian cancer by activating the proliferative activity of the cancerous cells (Liu et al. 2015a, Shi \& Zhang 2016, Wang et al. 2017, Fang et al. 2017). Since cancer development in the ovary is unusually caused by cell growth (by promoting the expression of anti-apoptotic genes and masking the role of apoptotic genes), miRNA could aggravate ovarian cancer by suppressing pro-apoptotic genes. Thus, miR$146 a-5 p$ is implicated in ovarian cancer development by suppressing the expression of anti-apoptotic genes, such as XIAP, BCL2L2 and BIRC5 (Li et al. 2017), and miR205 has been implicated in aggravating ovarian cancer by suppressing the expression of the tumor suppresser gene TCF21 (Wei et al. 2017).

Another pathophysiological disorder that affects female fertility is the occurrence of polycystic ovarian syndrome (PCOS) (Harris \& Terry 2016). Dysregulation of the ovarian miRNAs due to PCOS has been evidenced in many instances. Among others, 84 miRNAs, including miR-221, miR-222, let-7d and miR-26b, were found to be altered in the ovarian tissue of a PCOS rat model (Hossain et al. 2013). Also, decreased expression of miR$141-3 p$ in the ovaries of rat PCOS models was associated with apoptotic incidences in the granulosa cells by increasing the expression of death-associated protein kinase 1 (Li et al. 2017). Other authors have reported that reduced miR-145 expression in the granulosa cells of PCOS women might increase granulosa cell proliferation by activating the MAPK/ERK signaling pathways (Cai et al. 2017). Also, downregulation of miR-483 in PCOS ovaries is believed to enhance ovarian cell proliferation and survival (Xiang et al. 2016). Interestingly, upregulation of miRNA-509-3p in the cumulus cells of PCOS woman was found to increase estradiol secretion of the granulosa cells by inhibiting the expression of MAP3K8 (Huang et al. 2016b).

PCOS also induces miRNA expression alterations in the cumulus and granulosa cells. The downregulation of miRNAs has been implicated in reduced insulin resistance in the cumulus cell of PCOS woman (Shi et al. 2015). Furthermore, dysregulation of miRNAs is potentially involved in the Wnt signaling pathway, MAPK signaling pathways and progesterone-mediated oocyte maturation in cumulus cells (Liu et al. 2015b, Cai et al. 2017). In granulosa cells, activation of miR-93 (Jiang et al. 2015) and altered expression of 19 miRNAs (Shi et al. 2015) have been detected in the granulosa cells of PCOS woman. The extended effect of PCOS in the preimplantation period is also evidenced by suppression of let-7a, miR-19b, miR-24, miR-92 and miR-93 and induction of let-7b, let-7g and miR-34b in blastocysts derived from PCOS woman (McCallie et al.
2010). These findings indicate how the occurrence of PCOS could influence miRNA expression in the ovarian cortex, granulosa cells and even in the oocytes. However, altered expression of miRNAs due to PCOS is not limited to the ovarian tissue; changes in the abundance of the circulatory miRNAs were also observed in the blood plasma (Sathyapalan et al. 2015), serum (Jiang et al. 2016, Eisenberg et al. 2017, Xiong et al. 2017) and follicular fluid (Sørensen et al. 2016) of PCOS woman. These findings suggest that circulating miRNAs are potential biomarkers for the detection of PCOS.

\section{Extracellular mediated circulation of miRNAs and their role in reproduction}

Extracellular vesicles have been identified as important mediators of intercellular communication and are known to regulate a wide range of biological processes. Based on their cellular origin, extracellular vesicles can be designated as ectosomes (vesicles secreted by neutrophils or monocytes), microparticles (vesicles shed from platelets in blood and endothelial cells), prostatosomes (vesicles derived from seminal fluid), telerosomes (vesicles isolated from serum of antigen-fed mice) and cardiosomes (vesicles secreted by cardiomyocytes) (reviewed by EL Andaloussi et al. (2013)). Depending on their biogenesis and size, extracellular vesicles can be classified as exosomes (30-130 nm), microvesicles (50-1000 nm) and apoptotic bodies (500-2000 nm). Microvesicles are enriched in phosphatidylserine, and their membrane composition reflects that of the parent cell more closely than the membrane composition of exosomes (EL Andaloussi et al. 2013).

There is accumulated evidence of the importance of exosome-mediated cell-to-cell communication under pathological conditions. For example, circulating exosome-carried proteins can be used as diagnostic tools for cancer (Melo et al. 2015). Extracellular vesicles are present in reproductive tract fluid and potentially support early embryo development (Ng et al. 2013b, Ruiz-Gonzalez et al. 2015, Alminana et al. 2017). Protein characterization of extracellular vesicles from bovine oviductal fluid showed enrichment of proteins known to be involved in sperm-oocyte binding, fertilization and early embryo development (Alminana et al. 2017). During maternal embryonic crosstalk, vesicles are released by reproductive tract tissues and the embryo itself (Mellisho et al. 2017). In sheep, extracellular vesicles have been shown to have an important role in maternal embryonic crosstalk (Burns et al. 2016). This uptake of vesicles by various cell types is evidence of a role for those vesicles in cell-to-cell communication. In the course of this uptake, vesicles transfer their genetic material (e.g., mRNA, miRNAs) to the recipient cells, resulting in an increase in the level of endogenous miRNAs (Sohel et al. 2013). Although the molecular cargos of the extracellular vesicles are not characterized, 
the supplementation of extracellular vesicles isolated from bovine follicular fluid from $3-6 \mathrm{~mm}$ follicles into the maturation and early embryo culture had a significant effect on the mRNA, miRNAs, DNA methylation and hydroxymethylation patterns of the resulting blastocysts (da Silveira et al. 2017). Similarly, the co-incubation of extracellular vesicles isolated from the follicular fluid of small $(3-5 \mathrm{~mm})$ and large $(>9 \mathrm{~mm})$ bovine follicles promoted cumulus expansion with a concomitant induction of cumulus expansion marker genes (Hung et al. 2015). Significant effects on cumulus expansion and induction of marker genes were evident during the supplementation of extracellular vesicles from the small follicle. This might be attributed to the differences in the concentration of EVs between follicular fluid derived from small and large follicles (Hung et al. 2015) or the higher relative abundance of shuttle RNAs in follicular fluid from follicles harboring a growing oocyte (compared to the fully grown oocyte) (Sohel et al. 2013). However, comprehensive molecular analyses (at mRNA, miRNA and protein levels) of the EVs from the biological fluid of interest are needed for a complete understanding of the mechanisms involved.

According to the ExoCarta online exosome database (2017), a large number of proteins (9.769), mRNA (3408), miRNA (2838) and hundreds of lipids (http://exocarta. org) have been detected in exosomes (Keerthikumar et al. 2016). The number of publications addressing exosomes and their molecular content has increased dramatically in the last five years. A large body of evidence is available for the presence of miRNA-carrying extracellular vesicles in various biological fluids, and these play a significant role in cell-to-cell communication related to male and female reproduction. A panel of miRNAs circulating in blood serum can be used as indicators of various cancers, including prostate, lung and colorectal, with up to $100 \%$ specificity (Chen et al. 2008, Mitchell et al. 2008). Table 1 summarizes the circulatory miRNAs that regulate various physiological activities in multiple species.

Most importantly, miRNAs released into the extracellular environment and carried by vesicles, lipids or proteins are known to be highly stable, withstanding extreme conditions (e.g., frequent freezing and thawing). This property makes these miRNAs potential biomarkers for oocyte and embryo developmental competence. Bovine embryos cultured from day 5-8 in vitro release different miRNAs into the culture media depending on their developmental capacity (Kropp et al. 2014). In that study, it was shown that certain groups of miRNAs are more abundant in the culture media of degenerated embryos than blastocyst embryos. This is to be expected as degenerated blastocysts are prone to release cellular contents into an extracellular environment, not only through exosomes but also through larger vesicles and apoptotic bodies. In humans, cleaving and morula stage embryos release no miRNAs into spent culture media, whereas the blastocyst, which is mainly originated from trophectoderm cells, does release miRNAs (Capalbo et al. 2016). Retrospective analysis of miRNAs in spent media from unimplanted and implanted blastocysts revealed differential expression of miRNAs; miR-20a and miR-30c are highly abundant in spent media from implanted blastocysts and are predicted to target genes involved in cell-to-cell communication and signaling, cell adhesion and cell growth.

\section{Conclusion}

miRNAs play significant roles in regulating various processes in female reproductive axis starting from the primordial follicle activation through early embryo development and implantation for successful reproductive processes. In addition to their tissuespecific expression and role, large sets of miRNAs are also released into the extracellular space as key molecules for cell-to-cell communication or as cellular response to environmental stimuli. Despite the availability of large set of studies on the expression of miRNAs under various physiological conditions, so far, the functional roles of only few miRNAs have been determined in female reproduction. The functional analysis of miRNAs is mainly challenged by the complex interaction between miRNAs and mRNAs showing many-to-one and oneto-many relationships. However, due to their short size, but big impact on female reproductive processes, miRNAs could have a significant potential to be utilized as fertility markers and develop therapeutic tools for fertility-related problems in mammals.

\section{Declaration of interest}

The authors declare that there is no conflict of interest that could be perceived as prejudicing the impartiality of the review reported.

\section{Funding}

This review did not receive any specific grant from any funding agency in the public, commercial or not-for-profit sector.

\section{References}

Abd El Naby WS, Hagos TH, Hossain MM, Salilew-Wondim D, Gad AY, Rings F, Cinar MU, Tholen E, Looft C, Schellander K et al. 2013 Expression analysis of regulatory microRNAs in bovine cumulus-oocyte complex and preimplantation embryos. Zygote 21 31-51. (https://doi. org/10.1017/S0967199411000566)

Ahn HW, Morin RD, Zhao H, Harris RA, Coarfa C, Chen Z-J, Milosavljevic A, Marra MA \& Rajkovic A 2010 microRNA transcriptome in the newborn mouse ovaries determined by massively parallel sequencing. Molecular Human Reproduction 16 463-471. (https://doi.org/10.1093/ molehr/gaq017)

Alminana C, Corbin E, Tsikis G, Alcantara-Neto AS, Labas V, Reynaud K, Galio L, Uzbekov R, Garanina AS, Druart X et al. 2017 Oviduct extracellular vesicles protein content and their role during oviduct- 
embryo cross-talk. Reproduction 154 153-168. (https://doi.org/10.1530/ REP-17-0054)

An X, Song Y, Hou J, Li G, Zhao H, Wang J \& Cao B 2016 Identification and profiling of microRNAs in the ovaries of polytocous and monotocous goats during estrus. Theriogenology 85 769-780. (https://doi. org/10.1016/j.theriogenology.2015.09.056)

Andreas E, Hoelker M, Neuhoff C, Tholen E, Schellander K, Tesfaye D \& Salilew-Wondim D 2016 MicroRNA 17-92 cluster regulates proliferation and differentiation of bovine granulosa cells by targeting PTEN and BMPR2 genes. Cell and Tissue Research 319 219-230. (https://doi. org/10.1007/s00441-016-2425-7)

Baranyai T, Herczeg K, Onodi Z, Voszka I, Modos K, Marton N, Nagy G, Mager I, Wood MJ, El Andaloussi S et al. 2015 Isolation of exosomes from blood plasma: qualitative and quantitative comparison of ultracentrifugation and size exclusion chromatography methods. PLoS ONE 10 e0145686. (https://doi.org/10.1371/journal.pone.0145686)

Battaglia R, Vento ME, Ragusa M, Barbagallo D, La Ferlita A, Di Emidio G, Borzi P, Artini PG, Scollo P, Tatone C et al. 2016 MicroRNAs are stored in human mii oocyte and their expression profile changes in reproductive aging. Biology of Reproduction 95 131. (https://doi.org/10.1095/ biolreprod.116.142711)

Bernstein E, Kim SY, Carmell MA, Murchison EP, Alcorn H, Li MZ, Mills AA, Elledge SJ, Anderson KV \& Hannon GJ 2003 Dicer is essentia for mouse development. Nature Genetics 35 215-217. (https://doi. org/10.1038/ng1253)

Bettegowda A \& Smith GW 2007 Mechanisms of maternal mRNA regulation: implications for mammalian early embryonic development. Frontiers in Bioscience 12 3713-3726. (https://doi.org/10.2741/2346)

Braw-Tal R \& Yossefi S 1997 Studies in vivo and in vitro on the initiation of follicle growth in the bovine ovary. Journal of Reproduction and Fertility 109 165-171. (https://doi.org/10.1530/jrf.0.1090165)

Budna J, Rybska M, Ciesiółka S, Bryja A, Borys S, Kranc W, WojtanowiczMarkiewicz K, Jeseta M, Sumelka E, Bukowska D et al. 2017 Expression of genes associated with BMP signaling pathway in porcine oocytes before and after IVM - a microarray approach. Reproductive Biology and Endocrinology 15 43. (https://doi.org/10.1186/s12958-017-0261-6)

Burns GW, Brooks KE \& Spencer TE 2016 Extracellular vesicles originate from the conceptus and uterus during early pregnancy in sheep. Biology of Reproduction 94 56. (https://doi.org/10.1095/biolreprod.115.134973)

Cai G, Ma X, Chen B, Huang Y, Liu S, Yang H \& Zou W 2017 MicroRNA-145 negatively regulates cell proliferation through targeting IRS1 in isolated ovarian granulosa cells from patients with polycystic ovary syndrome. Reproductive Sciences 24 902-910. (https://doi. org/10.1177/1933719116673197)

Cao R, Wu WJ, Zhou XL, Xiao P, Wang Y \& Liu HL 2015 Expression and preliminary functional profiling of the let-7 family during porcine ovary follicle atresia. Molecules and Cells 38 304-311. (https://doi. org/10.14348/molcells.2015.2122)

Capalbo A, Ubaldi FM, Cimadomo D, Noli L, Khalaf Y, Farcomeni A, Ilic D \& Rienzi L 2016 MicroRNAs in spent blastocyst culture medium are derived from trophectoderm cells and can be explored for human embryo reproductive competence assessment. Fertility and Sterility 105 225.e1-3-35.e1-3. (https://doi.org/10.1016/j.fertnstert.2015.09.014)

Carletti MZ, Fiedler SD \& Christenson LK 2010 MicroRNA 21 blocks apoptosis in mouse periovulatory granulosa cells. Biology of Reproduction 83 286-295. (https://doi.org/10.1095/biolreprod.109.081448)

Castellano L \& Stebbing J 2013 Deep sequencing of small RNAs identifies canonical and non-canonical miRNA and endogenous siRNAs in mammalian somatic tissues. Nucleic Acids Research 41 3339-3351. (https://doi.org/10.1093/nar/gks1474)

Chen X, Ba Y, Ma L, Cai X, Yin Y, Wang K, Guo J, Zhang Y, Chen J, Guo X et al. 2008 Characterization of microRNAs in serum: a novel class of biomarkers for diagnosis of cancer and other diseases. Cell Research $\mathbf{1 8}$ 997-1006. (https://doi.org/10.1038/cr.2008.282)

Chen X, Xie M, Liu D \& Shi K 2015 Downregulation of microRNA146a inhibits ovarian granulosa cell apoptosis by simultaneously targeting interleukin1 receptorassociated kinase and tumor necrosis factor receptorassociated factor 6. Molecular Medicine Reports 12 5155-5162. (https://doi.org/10.3892/mmr.2015.4036)

da Silveira JC, Carnevale EM, Winger QA \& Bouma GJ 2014 Regulation of ACVR1 and ID2 by cell-secreted exosomes during follicle maturation in the mare. Reproductive Biology Endocrinology 12 44. (https://doi. org/10.1186/1477-7827-12-44) da Silveira JC, Andrade GM, Del Collado M, Sampaio RV, Sangalli JR, Silva LA, Pinaffi FVL, Jardim IB, Cesar MC, Nogueira MFG et al. 2017 Supplementation with small-extracellular vesicles from ovarian follicular fluid during in vitro production modulates bovine embryo development. PLOS ONE 12 e0179451. (https://doi.org/10.1371/journal. pone.0179451)

Dai A, Sun H, Fang T, Zhang Q, Wu S, Jiang Y, Ding L, Yan G \& Hu Y 2013 MicroRNA-133b stimulates ovarian estradiol synthesis by targeting Foxl2. FEBS Letters 587 2474-2482. (https://doi.org/10.1016/j. febslet.2013.06.023)

Dalzell JJ, Warnock ND, Stevenson MA, Mousley A, Fleming CC \& Maule AG 2010 Short interfering RNA-mediated knockdown of drosha and pasha in undifferentiated Meloidogyne incognita eggs leads to irregular growth and embryonic lethality. International Journal for Parasitology $\mathbf{4 0}$ 1303-1310. (https://doi.org/10.1016/j.ijpara.2010.03.010)

Di R, He J, Song S, Tian D, Liu Q, Liang X, Ma Q, Sun M, Wang J, Zhao W et al. 2014 Characterization and comparative profiling of ovarian microRNAs during ovine anestrus and the breeding season. BMC Genomics 15 899. (https://doi.org/10.1186/1471-2164-15-899)

Diederichs S \& Haber DA 2007 Dual role for argonautes in microRNA processing and posttranscriptional regulation of microRNA expression. Cell 131 1097-1108. (https://doi.org/10.1016/j.cell.2007.10.032)

Diez-Fraile A, Lammens T, Tilleman K, Witkowski W, Verhasselt B, de Sutter P, Benoit Y, Espeel M \& D'Herde K 2014 Age-associated differential microRNA levels in human follicular fluid reveal pathways potentially determining fertility and success of in vitro fertilization. Human Fertility 17 90-98. (https://doi.org/10.3109/14647273.2014.89 7006)

Donadeu FX, Sontakke SD \& Ioannidis J 2016 MicroRNA indicators of follicular steroidogenesis. Reproduction, Fertility, and Development 29 906-912. (https://doi.org/10.1071/RD15282)

Eisenberg I, Nahmias N, Novoselsky Persky M, Greenfield C, GoldmanWohl D, Hurwitz A, Haimov-Kochman R, Yagel S \& Imbar T 2017 Elevated circulating micro-ribonucleic acid (miRNA)-200b and miRNA-429 levels in anovulatory women. Fertility and Sterility $\mathbf{1 0 7}$ 269-275. (https://doi.org/10.1016/j.fertnstert.2016.10.003)

EL Andaloussi S, Mager I, Breakefield XO \& Wood MJA 2013 Extracellular vesicles: biology and emerging therapeutic opportunities. Nature Reviews Drug Discovery 12 347-357. (https://doi.org/10.1038/nrd3978)

Eppig JJ 1996 Coordination of nuclear and cytoplasmic oocyte maturation in eutherian mammals. Reproduction, Fertility, and Development 8 485-489. (https://doi.org/10.1071/RD9960485)

Espey LL 1980 Ovulation as an inflammatory reaction: a hypothesis. Biology of Reproduction 22 73-106. (https://doi.org/10.1095/biolreprod22.1.73)

Espey LL 1994 Current status of the hypothesis that mammalian ovulation is comparable to an inflammatory reaction. Biology of Reproduction $\mathbf{5 0}$ 233-238. (https://doi.org/10.1095/biolreprod50.2.233)

Fair T, Carter F, Park S, Evans ACO \& Lonergan P 2007 Global gene expression analysis during bovine oocyte in vitro maturation. Theriogenology 68 (Supplement 1) S91-S97. (https://doi.org/10.1016/j. theriogenology.2007.04.018)

Fang G, Liu J, Wang Q, Huang X, Yang R, Pang Y \& Yang M 2017 MicroRNA223-3p regulates ovarian cancer cell proliferation and invasion by targeting SOX11 expression. International Journal of Molecular Sciences 18 1208. (https://doi.org/10.3390/ijms18061208)

Feng R, Sang Q, Zhu Y, Fu W, Liu M, Xu Y, Shi H, Xu Y, Qu R, Chai R et al. 2015 MiRNA-320 in the human follicular fluid is associated with embryo quality in vivo and affects mouse embryonic development in vitro. Scientific reports 5 8689. (https://doi.org/10.1038/srep08689)

Fiedler SD, Carletti MZ, Hong X \& Christenson LK 2008 Hormonal regulation of microRNA expression in periovulatory mouse mural granulosa cells. Biology of Reproduction 79 1030-1037. (https://doi. org/10.1095/biolreprod.108.069690)

Fortune JE 1994 Ovarian follicular growth and development in mammals. Biology of Reproduction 50 225-232. (https://doi.org/10.1095/ biolreprod50.2.225)

Fortune JE, Cushman RA, Wahl CM \& Kito S 2000 The primordial to primary follicle transition. Molecular and Cellular Endocrinology 163 53-60. (https://doi.org/10.1016/S0303-7207(99)00240-3)

Gebremedhn S, Salilew-Wondim D, Ahmad I, Sahadevan S, Hossain MM, Hoelker M, Rings F, Neuhoff C, Tholen E, Looft C et al. 2015 MicroRNA expression profile in bovine granulosa cells of preovulatory dominant and subordinate follicles during the late follicular phase of the estrous 
cycle. PLOS ONE 10 e0125912. (https://doi.org/10.1371/journal. pone.0125912)

Gebremedhn S, Salilew-Wondim D, Hoelker M, Rings F, Neuhoff C, Tholen E, Schellander K \& Tesfaye D 2016 MicroRNA-183-96-182 cluster regulates bovine granulosa cell proliferation and cell cycle transition by coordinately targeting FOXO1. Biology of Reproduction 94 127. (https://doi.org/10.1095/biolreprod.115.137539)

Ginther OJ, Kot K, Kulick LJ \& Wiltbank MC 1997 Emergence and deviation of follicles during the development of follicular waves in cattle. Theriogenology 48 75-87. (https://doi.org/10.1016/S0093691X(97)00192-1)

Giraldez AJ, Mishima Y, Rihel J, Grocock RJ, van Dongen S, Inoue K, Enright AJ \& Schier AF 2006 Zebrafish MiR-430 promotes deadenylation and clearance of maternal mRNAs. Science 312 75-79. (https://doi. org/10.1126/science.1122689)

Gonzalez G \& Behringer RR 2009 Dicer is required for female reproductive tract development and fertility in the mouse. Molecular Reproduction and Development 76 678-688. (https://doi.org/10.1002/mrd.21010)

Gregory RI, Yan KP, Amuthan G, Chendrimada T, Doratotaj B, Cooch N \& Shiekhattar R 2004 The microprocessor complex mediates the genesis of microRNAs. Nature 432 235-240. (https://doi.org/10.1038/ nature03120)

Ha M \& Kim VN 2014 Regulation of microRNA biogenesis. Nature Reviews Molecular Cell Biology 15 509-524. (https://doi.org/10.1038/nrm3838)

Harris HR \& Terry KL 2016 Polycystic ovary syndrome and risk of endometrial, ovarian, and breast cancer: a systematic review. Fertility Research and Practice 2 14. (https://doi.org/10.1186/s40738-0160029-2)

Hatzirodos N, Hummitzsch K, Irving-Rodgers HF, Harland ML, Morris SE \& Rodgers RJ 2014a Transcriptome profiling of granulosa cells from bovine ovarian follicles during atresia. BMC Cenomics 15 40. (https:// doi.org/10.1186/1471-2164-15-40)

Hatzirodos N, Irving-Rodgers HF, Hummitzsch K, Harland ML, Morris SE \& Rodgers RJ 2014b Transcriptome profiling of granulosa cells of bovine ovarian follicles during growth from small to large antral sizes. BMC Genomics 15 24. (https://doi.org/10.1186/1471-2164-15-24)

Havens MA, Reich AA, Duelli DM \& Hastings ML 2012 Biogenesis of mammalian microRNAs by a non-canonical processing pathway. Nucleic Acids Research 40 4626-4640. (https://doi.org/10.1093/nar/ gks026)

Hirshfield AN 1991 Development of follicles in the mammalian ovary. International Review of Cytology 124 43-101. (https://doi.org/10.1016/ s0074-7696(08)61524-7)

Hong X, Luense LJ, McGinnis LK, Nothnick WB \& Christenson LK 2008 Dicer1 is essential for female fertility and normal development of the female reproductive system. Endocrinology 149 6207-6212. (https://doi. org/10.1210/en.2008-0294)

Hossain MM, Ghanem N, Hoelker M, Rings F, Phatsara C, Tholen E, Schellander K \& Tesfaye D 2009 Identification and characterization of miRNAs expressed in the bovine ovary. BMC Genomics 10 443. (https:// doi.org/10.1186/1471-2164-10-443)

Hossain MM, Cao M, Wang Q, Kim JY, Schellander K, Tesfaye D \& Tsang BK 2013 Altered expression of miRNAs in a dihydrotestosteroneinduced rat PCOS model. Journal of Ovarian Research 6 36. (https://doi. org/10.1186/1757-2215-6-36)

Hsueh AJ, Adashi EY, Jones PB \& Welsh TH Jr 1984 Hormonal regulation of the differentiation of cultured ovarian granulosa cells. Endocrine Reviews 5 76-127. (https://doi.org/10.1210/edrv-5-1-76)

Hu Z, Shen W-J, Kraemer FB \& Azhar S 2012 MicroRNAs 125a and 455 Repress Lipoprotein-Supported Steroidogenesis by Targeting Scavenger Receptor Class B Type I in Steroidogenic Cells. Molecular and Cellular Biology 32 5035-5045. (https://doi.org/10.1128/MCB.01002-12)

Huang L, Yin ZJ, Feng YF, Zhang XD, Wu T, Ding YY, Ye PF, Fu K \& Zhang MQ 2016a Identification and differential expression of microRNAs in the ovaries of pigs (Sus scrofa) with high and low litter sizes. Animal Genetics 47 543-551. (https://doi.org/10.1111/age.12452)

Huang X, Liu C, Hao C, Tang Q, Liu R, Lin S, Zhang L \& Yan W 2016 b Identification of altered microRNAs and mRNAs in the cumulus cells of PCOS patients: miRNA-509-3p promotes oestradiol secretion by targeting MAP3K8. Reproduction 151 643-655. (https://doi.org/10.1530/ REP-16-0071)
Hughes FM Jr \& Gorospe WC 1991 Biochemical identification of apoptosis (programmed cell death) in granulosa cells: evidence for a potential mechanism underlying follicular atresia. Endocrinology 129 2415-2422. (https://doi.org/10.1210/endo-129-5-2415)

Hung WT, Hong X, Christenson LK \& McGinnis LK 2015 Extracellular vesicles from bovine follicular fluid support cumulus expansion. Biology of Reproduction 93 117. (https://doi.org/10.1095/ biolreprod.115.132977)

Hutvagner G \& Zamore PD 2002 A microRNA in a multiple-turnover RNAi enzyme complex. Science 297 2056-2060. (https://doi.org/10.1126/ science.1073827)

Hutvagner G, McLachlan J, Pasquinelli AE, Balint E, Tuschl T \& Zamore PD 2001 A cellular function for the RNA-interference enzyme Dicer in the maturation of the let-7 small temporal RNA. Science 293 834-838. (https://doi.org/10.1126/science.1062961)

Imbar T \& Eisenberg I 2014 Regulatory role of microRNAs in ovarian function. Fertility and Sterility 101 1524-1530. (https://doi.org/10.1016/j. fertnstert.2014.04.024)

Jiajie T, Yanzhou Y, Hoi-Hung AC, Zi-Jiang C \& Wai-Yee C 2017 Conserved miR-10 family represses proliferation and induces apoptosis in ovarian granulosa cells. Scientific Reports 7 41304. (https://doi.org/10.1038/ srep41304)

Jiang L, Huang J, Li L, Chen Y, Chen X, Zhao X \& Yang D 2015 MicroRNA-93 promotes ovarian granulosa cells proliferation through targeting CDKN1 A in polycystic ovarian syndrome. Journal of Clinical Endocrinology and Metabolism 100 E729-E738. (https://doi.org/10.1210/jc.2014-3827)

Jiang L, Huang J, Chen Y, Yang Y, Li R, Li Y, Chen X \& Yang D 2016 Identification of several circulating microRNAs from a genome-wide circulating microRNA expression profile as potential biomarkers for impaired glucose metabolism in polycystic ovarian syndrome. Endocrine 53 280-290. (https://doi.org/10.1007/s12020-016-0878-9)

Kaneda M, Tang F, O’Carroll D, Lao K \& Surani MA 2009 Essential role for Argonaute2 protein in mouse oogenesis. Epigenetics and Chromatin 29. (https://doi.org/10.1186/1756-8935-2-9)

Karakaya C, Guzeloglu-Kayisli O, Uyar A, Kallen AN, Babayev E, Bozkurt N, Unsal E, Karabacak O \& Seli E 2015 Poor ovarian response in women undergoing in vitro fertilization is associated with altered microRNA expression in cumulus cells. Fertility and Sterility 103 1469-76.e1-3. (https://doi.org/10.1016/j.fertnstert.2015.02.035)

Keerthikumar S, Chisanga D, Ariyaratne D, Al Saffar H, Anand S, Zhao K, Samuel M, Pathan M, Jois M, Chilamkurti N et al. 2016 ExoCarta: a web-based compendium of exosomal cargo. Journal of Molecular Biology 428 688-692. (https://doi.org/10.1016/j.jmb.2015.09.019)

Kim YJ, Ku SY, Kim YY, Liu HC, Chi SW, Kim SH, Choi YM, Kim JG \& Moon SY 2013 MicroRNAs transfected into granulosa cells may regulate oocyte meiotic competence during in vitro maturation of mouse follicles. Human Reproduction 28 3050-3061. (https://doi.org/10.1093/humrep/det338)

Kim YS, Kim H-R, Kim H, Yang SC, Park M, Yoon JA, Lim HJ, Hong S-H, DeMayo FJ, Lydon JP et al. 2016 Deficiency in DGCR8-dependent canonical microRNAs causes infertility due to multiple abnormalities during uterine development in mice. Scientific Reports 6 20242. (https:// doi.org/10.1038/srep20242)

Kitahara Y, Nakamura K, Kogure K \& Minegishi T 2013 Role of microRNA$136-3 p$ on the expression of luteinizing hormone-human chorionic gonadotropin receptor mRNA in rat ovaries. Biology of Reproduction 89 114. (https://doi.org/10.1095/biolreprod.113.109207)

Kropp J, Salih SM \& Khatib H 2014 Expression of microRNAs in bovine and human pre-implantation embryo culture media. Frontiers in Genetics $\mathbf{5}$ 91. (https://doi.org/10.3389/fgene.2014.00091)

Lasko P 2011 Posttranscriptional regulation in Drosophila oocytes and early embryos. Wiley Interdisciplinary Reviews: RNA 2 408-416. (https:// doi.org/10.1002/wrna.70)

Lee RC, Feinbaum RL \& Ambros V 1993 The C. elegans heterochronic gene lin-4 encodes small RNAs with antisense complementarity to lin-14. Cell 75 843-854. (https://doi.org/10.1016/0092-8674(93)90529-Y)

Lee Y, Ahn C, Han J, Choi H, Kim J, Yim J, Lee J, Provost P, Rådmark O, Kim $\mathbf{S}$ et al. 2003 The nuclear RNase III Drosha initiates microRNA processing. Nature 425 415-419. (https://doi.org/10.1038/nature01957) Lee Y, Kim M, Han J, Yeom K-H, Lee S, Baek SH \& Kim VN 2004 MicroRNA genes are transcribed by RNA polymerase II. EMBO Journal 23 4051-4060. (https://doi.org/10.1038/sj.emboj.7600385) 
Lei L, Jin S, Gonzalez G, Behringer RR \& Woodruff TK 2010 The regulatory role of Dicer in folliculogenesis in mice. Molecular and Cellular Endocrinology 315 63. (https://doi.org/10.1016/j.mce.2009.09.021)

Li L, Zheng P \& Dean J 2010 Maternal control of early mouse development. Development 137 859-870. (https://doi.org/10.1242/dev.039487)

Li M, Liu Y, Wang T, Guan J, Luo Z, Chen H, Wang X, Chen L, Ma J, Mu Z et al. 2011 Repertoire of porcine microRNAs in adult ovary and testis by deep sequencing. International Journal of Biological Sciences 7 1045-1055. (https://doi.org/10.7150/ijbs.7.1045)

Li P, Meng J, Liu W, Smith GW, Yao J \& Lyu L 2016 Transcriptome analysis of bovine ovarian follicles at predeviation and onset of deviation stages of a follicular wave. International Journal of Genomics 20163472748. (https://doi.org/10.1155/2016/3472748)

Li X, Jin Y, Mu Z, Chen W \& Jiang S 2017 MicroRNA-146a-5p enhances cisplatin-induced apoptosis in ovarian cancer cells by targeting multiple anti-apoptotic genes. International Journal of Oncology 51 327-335. (https://doi.org/10.3892/ijo.2017.4023)

Liang Y, Ridzon D, Wong L \& Chen C 2007 Characterization of microRNA expression profiles in normal human tissues. BMC Genomics 8166. (https://doi.org/10.1186/1471-2164-8-166)

Lim LP, Glasner ME, Yekta S, Burge CB \& Bartel DP 2003 Vertebrate microRNA genes. Science 299 1540. (https://doi.org/10.1126/ science.1080372)

Lin F, Li R, Pan ZX, Zhou B, Yu DB, Wang XG, Ma XS, Han J, Shen M \& Liu HL 2012 miR-26b promotes granulosa cell apoptosis by targeting ATM during follicular atresia in porcine ovary. PLOS ONE 7 e38640. (https://doi.org/10.1371/journal.pone.0038640)

Ling Y-H, Ren C-H, Guo X-F, Xu L-N, Huang Y-F, Luo J-C, Zhang Y-H, Zhang X-R \& Zhang Z-J 2014 Identification and characterization of microRNAs in the ovaries of multiple and uniparous goats (Capra hircus) during follicular phase. BMC Genomics 15 339. (https://doi. org/10.1186/1471-2164-15-339)

Liu HC, Tang Y, He Z \& Rosenwaks Z 2010 Dicer is a key player in oocyte maturation. Journal of Assisted Reproduction and Genetics 27 571-580. (https://doi.org/10.1007/s10815-010-9456-x)

Liu J, Yao W, Yao Y, Du X, Zhou J, Ma B, Liu H, Li Q \& Pan Z 2014 MiR92a inhibits porcine ovarian granulosa cell apoptosis by targeting Smad7 gene. FEBS Letters 588 4497-4503. (https://doi.org/10.1016/j. febslet.2014.10.021)

Liu S, Zhang X, Shi C, Lin J, Chen G, Wu B, Wu L, Shi H, Yuan Y, Zhou W et al. 2015a Altered microRNAs expression profiling in cumulus cells from patients with polycystic ovary syndrome. Journal of Translational Medicine 13 238. (https://doi.org/10.1186/s12967-015-0605-y)

Liu X, Ma L, Rao Q, Mao Y, Xin Y, Xu H, Li C \& Wang X 2015b MiR-1271 inhibits ovarian cancer growth by targeting cyclin G1. Medical Science Monitor 21 3152-3158. (https://doi.org/10.12659/msm.895562)

Liu J, Tu F, Yao W, Li X, Xie Z, Liu H, Li Q \& Pan Z 2016 Conserved miR-26b enhances ovarian granulosa cell apoptosis through HAS2-HA-CD44Caspase-3 pathway by targeting HAS2. Scientific Reports 621197. (https://doi.org/10.1038/srep21197)

Liu P, Qi X, Bian C, Yang F, Lin X, Zhou S, Xie C, Zhao X \& Yi T 2017a MicroRNA-18a inhibits ovarian cancer growth via directly targeting TRIAP1 and IPMK. Oncology Letters 13 4039-4046. (https://doi. org/10.3892/ol.2017.5961)

Liu W, Zhao Q, Piao S, Wang C, Kong Q \& An T 2017b Endo-siRNA deficiency results in oocyte maturation failure and apoptosis in porcine oocytes. Reproduction, Fertility, and Development 29 2168-2174. (https://doi.org/10.1071/RD16498)

Luense LJ, Carletti MZ \& Christenson LK 2009 Role of Dicer in female fertility. Trends in Endocrinology and Metabolism: TEM 20 265-272. (https://doi.org/10.1016/j.tem.2009.05.001)

Maruo T 1995 Expression of oncogenes, growth factors and their receptors in follicular growth, regression and atresia: their roles in granulosa cell proliferation and differentiation. Nihon Sanka Fujinka Gakkai Zasshi $\mathbf{4 7}$ 738-750.

Mattiske DM, Han L \& Mann JR 2009 Meiotic maturation failure induced by DICER1 deficiency is derived from primary oocyte ooplasm. Reproduction 137 625-632. (https://doi.org/10.1530/REP-08-0475)

McCallie B, Schoolcraft WB \& Katz-Jaffe MG 2010 Aberration of blastocyst microRNA expression is associated with human infertility. Fertility and Sterility 93 2374-2382. (https://doi.org/10.1016/j.fertnstert.2009.01.069)
Mellisho EA, Velasquez AE, Nunez MJ, Cabezas JG, Cueto JA, Fader C, Castro FO \& Rodriguez-Alvarez L 2017 Identification and characteristics of extracellular vesicles from bovine blastocysts produced in vitro. PLoS ONE 12 e0178306. (https://doi.org/10.1371/journal.pone.0178306)

Melo SA, Luecke LB, Kahlert C, Fernandez AF, Gammon ST, Kaye J, LeBleu VS, Mittendorf EA, Weitz J, Rahbari N et al. 2015 Glypican1 identifies cancer exosomes and facilitates early detection of cancer. Nature 523 177-182. (https://doi.org/10.1038/nature14581)

Memili E \& First NL 1999 Control of gene expression at the onset of bovine embryonic development. Biology of Reproduction 61 1198-1207. (https://doi.org/10.1095/biolreprod61.5.1198)

Miles JR, Mcdaneld TG, Wiedmann RT, Cushman RA, Echternkamp SE, Vallet JL \& Smith TPL 2012 MicroRNA expression profile in bovine cumulus-oocyte complexes: possible role of let-7 and miR-106a in the development of bovine oocytes. Animal Reproduction Science $\mathbf{1 3 0}$ 16-26. (https://doi.org/10.1016/j.anireprosci.2011.12.021)

Mitchell PS, Parkin RK, Kroh EM, Fritz BR, Wyman SK, PogosovaAgadjanyan EL, Peterson A, Noteboom J, O'Briant KC, Allen A et al. 2008 Circulating microRNAs as stable blood-based markers for cancer detection. PNAS 105 10513-10518. (https://doi.org/10.1073/ pnas.0804549105)

Miyazawa K, Shinozaki M, Hara T, Furuya T \& Miyazono K 2002 Two major Smad pathways in TGF-beta superfamily signalling. Genes to Cells Devoted to Molecular and Cellular Mechanisms 7 1191-1204. (https:// doi.org/10.1046/j.1365-2443.2002.00599.x)

Mondou E, Dufort I, Gohin M, Fournier E \& Sirard MA 2012 Analysis of microRNAs and their precursors in bovine early embryonic development. Molecular Human Reproduction 18 425-434. (https://doi.org/10.1093/ molehr/gas015)

Mtango NR, Potireddy S \& Latham KE 2009 Expression of microRNA processing machinery genes in rhesus monkey oocytes and embryos of different developmental potentials. Molecular Reproduction and Development 76 255-269. (https://doi.org/10.1002/mrd.20950)

Muggenhumer D, Vesely C, Nimpf S, Tian N, Yongfeng J \& Jantsch MF 2014 Drosha protein levels are translationally regulated during Xenopus oocyte maturation. Molecular Biology of the Cell 25 2094-2104. (https:// doi.org/10.1091/mbc.E13-07-0386)

Murchison EP, Stein P, Xuan Z, Pan H, Zhang MQ, Schultz RM \& Hannon GJ 2007 Critical roles for Dicer in the female germline. Genes and Development 21 682-693. (https://doi.org/10.1101/gad.1521307)

Nagaraja AK, Andreu-Vieyra C, Franco HL, Ma L, Chen R, Han DY, Zhu H, Agno JE, Gunaratne PH, DeMayo FJ et al. 2008 Deletion of Dicer in somatic cells of the female reproductive tract causes sterility. Molecular Endocrinology 22 2336-2352. (https://doi.org/10.1210/me.2008-0142)

Navakanitworakul R, Hung WT, Gunewardena S, Davis JS, Chotigeat W \& Christenson LK 2016 Characterization and Small RNA Content of Extracellular Vesicles in Follicular Fluid of Developing Bovine Antral Follicles. Scientific Reports 6 25486. (https://doi.org/10.1038/srep25486)

$\mathrm{Ng} \mathrm{YH}$, Rome S, Jalabert A, Forterre A, Singh H, Hincks CL \& Salamonsen LA 2013b Endometrial exosomes/microvesicles in the uterine microenvironment: a new paradigm for embryo-endometrial cross talk at implantation. PLoS ONE 8 e58502. (https://doi.org/10.1371/ journal.pone.0058502)

Nie M, Yu S, Peng S, Fang Y, Wang H \& Yang X 2015 miR-23a and miR-27a promote human granulosa cell apoptosis by targeting SMAD5. Biology of Reproduction 93 98. (https://doi.org/10.1095/biolreprod.115.130690)

Noferesti SS, Sohel MMH, Hoelker M, Salilew-Wondim D, Tholen E, Looft C, Rings F, Neuhoff C, Schellander K \& Tesfaye D 2015 Controlled ovarian hyperstimulation induced changes in the expression of circulatory miRNA in bovine follicular fluid and blood plasma. Journal of Ovarian Research 8 81. (https://doi.org/10.1186/s13048-015-0208-5)

Otsuka M, Zheng M, Hayashi M, Lee J-D, Yoshino O, Lin S \& Han J 2008 Impaired microRNA processing causes corpus luteum insufficiency and infertility in mice. Journal of Clinical Investigation 118 1944-1954. (https://doi.org/10.1172/JCl33680)

Pan B, Toms D, Shen W \& Li J 2015 MicroRNA-378 regulates oocyte maturation via the suppression of aromatase in porcine cumulus cells. American Journal of Physiology: Endocrinology and Metabolism 308 E525-E534. (https://doi.org/10.1152/ajpendo.00480.2014)

Pang RT, Liu WM, Leung CO, Ye TM, Kwan PC, Lee KF et al. 2011 miR135A Regulates Preimplantation Embryo Development through Down- 
Regulation of E3 Ubiquitin Ligase Seven in Absentia Homolog 1A (SIAH1A) Expression. PLoS One 6 e27878.

Peng JY, An XP, Fang F, Gao KX, Xin HY, Han P, Bao LJ, Ma HD \& Cao BY 2016 MicroRNA-10b suppresses goat granulosa cell proliferation by targeting brain-derived neurotropic factor. Domestic Animal Endocrinology $\mathbf{5 4}$ 60-67. (https://doi.org/10.1016/j.domaniend.2015.09.005)

Raposo G \& Stoorvogel W 2013 Extracellular vesicles: exosomes, microvesicles, and friends. Journal of Cell Biology 200 373-383. (https:// doi.org/10.1083/jcb.201211138)

Rios C, Warren D, Olson B \& Abbott AL 2017 Functional analysis of microRNA pathway genes in the somatic gonad and germ cells during ovulation in C. elegans. Developmental Biology 426 115-125. (https:// doi.org/10.1016/j.ydbio.2017.04.007)

Ro S, Song R, Park C, Zheng H, Sanders KM \& Yan W 2007 Cloning and expression profiling of small RNAs expressed in the mouse ovary. RNA 13 2366-2380. (https://doi.org/10.1261/rna.754207)

Ruby JG, Jan CH \& Bartel DP 2007 Intronic microRNA precursors that bypass Drosha processing. Nature 448 83-86. (https://doi.org/10.1038/ nature05983)

Ruiz-Gonzalez I, Xu J, Wang X, Burghardt RC, Dunlap KA \& Bazer FW 2015 Exosomes, endogenous retroviruses and toll-like receptors: pregnancy recognition in ewes. Reproduction 149 281-291. (https://doi. org/10.1530/REP-14-0538)

Salilew-Wondim D, Ahmad I, Gebremedhn S, Sahadevan S, Hossain MDM, Rings F, Hoelker M, Tholen E, Neuhoff C, Looft C et al. 2014 The expression pattern of microRNAs in granulosa cells of subordinate and dominant follicles during the early luteal phase of the bovine estrous cycle. PLOS ONE 9 e106795. (https://doi.org/10.1371/journal. pone.0106795)

Sathyapalan T, David R, Gooderham NJ \& Atkin SL 2015 Increased expression of circulating miRNA-93 in women with polycystic ovary syndrome may represent a novel, non-invasive biomarker for diagnosis. Scientific Reports 5 16890. (https://doi.org/10.1038/srep16890)

Scalici E, Traver S, Mullet T, Molinari N, Ferrieres A, Brunet C, Belloc S \& Hamamah S 2016 Circulating microRNAs in follicular fluid, powerful tools to explore in vitro fertilization process. Scientific Reports $\mathbf{6} 24976$. (https://doi.org/10.1038/srep24976)

Schauer SN, Sontakke SD, Watson ED, Esteves CL \& Donadeu FX 2013 Involvement of miRNAs in equine follicle development. Reproduction 146 273-282. (https://doi.org/10.1530/REP-13-0107)

Schultz RM 1993 Regulation of zygotic gene activation in the mouse BioEssays News and Reviews in Molecular, Cellular and Developmental Biology 15 531-538. (https://doi.org/10.1002/bies.950150806)

Shi C \& Zhang Z 2016 miR-761 inhibits tumor progression by targeting MSI1 in ovarian carcinoma. Tumour Biology 37 5437-5443. (https://doi. org/10.1007/s13277-015-4377-z)

Shi L, Liu S, Zhao W \& Shi J 2015 miR-483-5p and miR-486-5p are down-regulated in cumulus cells of metaphase II oocytes from women with polycystic ovary syndrome. Reproductive Biomedicine Online $\mathbf{3 1}$ 565-572. (https://doi.org/10.1016/j.rbmo.2015.06.023)

Sinha PB, Tesfaye D, Rings F, Hossien M, Hoelker M, Held E, Neuhoff C, Tholen E, Schellander K \& Salilew-Wondim D 2017 MicroRNA-130b is involved in bovine granulosa and cumulus cells function, oocyte maturation and blastocyst formation. Journal of Ovarian Research 1037. (https://doi.org/10.1186/s13048-017-0336-1)

Sirotkin AV, Ovcharenko D, Grossmann R, Laukova M \& Mlyncek M 2009 Identification of microRNAs controlling human ovarian cell steroidogenesis via a genome-scale screen. Journal of Cellular Physiology 219 415-420. (https://doi.org/10.1002/jcp.21689)

Sirotkin AV, Laukova M, Ovcharenko D, Brenaut P \& Mlyncek M 2010 Identification of microRNAs controlling human ovarian cell proliferation and apoptosis. Journal of Cellular Physiology 223 49-56. (https://doi. org/10.1002/jcp.21999)

Sirotkin AV, Kisova G, Brenaut P, Ovcharenko D, Grossmann R \& Mlyncek M 2014 Involvement of microRNA Mir15a in control of human ovarian granulosa cell proliferation, apoptosis, steroidogenesis, and response to FSH. MicroRNA 3 29-36. (https://doi.org/10.2174/221153 6603666140227232824)

Sohel MMH, Hoelker M, Noferesti SS, Salilew-Wondim D, Tholen E, Looft C, Rings F, Uddin MJ, Spencer TE, Schellander K et al. 2013 Exosomal and non-exosomal transport of extra-cellular micrornas in follicular fluid: implications for bovine oocyte developmental competence. PLOS ONE 8 e78505. (https://doi.org/10.1371/journal. pone.0078505)

Song C, Yao J, Cao C, Liang X, Huang J, Han Z, Zhang Y, Qin G, Tao C, Li C et al. 2016 PPARgamma is regulated by miR-27b-3p negatively and plays an important role in porcine oocyte maturation. Biochemical and Biophysical Research Communications 479 224-230. (https://doi. org/10.1016/j.bbrc.2016.09.046)

Sontakke SD, Mohammed BT, McNeilly AS \& Donadeu FX 2014 Characterization of microRNAs differentially expressed during bovine follicle development. Reproduction 148 271-283. (https://doi. org/10.1530/REP-14-0140)

Sørensen AE, Wissing ML, Englund ALM \& Dalgaard LT 2016 MicroRNA species in follicular fluid associating with polycystic ovary syndrome and related intermediary phenotypes. Journal of Clinical Endocrinology and Metabolism 101 1579-1589. (https://doi.org/10.1210/jc.2015-3588)

Suh N, Baehner L, Moltzahn F, Melton C, Shenoy A, Chen J \& Blelloch R 2010 MicroRNA function is globally suppressed in mouse oocytes and early embryos. Current Biology 20 271-277. (https://doi.org/10.1016/j. cub.2009.12.044)

Su H, Trombly MI, Chen J \& Wang X 2009. Essential and overlapping functions for mammalian Argonautes in microRNA silencing. Genes and Development 23 304-317. (https://doi.org/10.1101/gad.1749809)

Tang F, Kaneda M, O’Carroll D, Hajkova P, Barton SC, Sun YA, Lee C, Tarakhovsky A, Lao K \& Surani MA 2007 Maternal microRNAs are essential for mouse zygotic development. Genes and Development 21 644-648. (https://doi.org/10.1101/gad.418707)

Telford NA, Watson AJ \& Schultz GA 1990 Transition from maternal to embryonic control in early mammalian development: a comparison of several species. Molecular Reproduction and Development 26 90-100. (https://doi.org/10.1002/mrd.1080260113)

Tesfaye D, Worku D, Rings F, Phatsara C, Tholen E, Schellander K \& Hoelker M 2009 Identification and expression profiling of microRNAs during bovine oocyte maturation using heterologous approach. Molecular Reproduction and Development 76 665-677. (https://doi. org/10.1002/mrd.21005)

Toms D, Xu S, Pan B, Wu D \& Li J 2015 Progesterone receptor expression in granulosa cells is suppressed by microRNA-378-3p. Molecular and Cellular Endocrinology 399 95-102. (https://doi.org/10.1016/j. mce.2014.07.022)

Tu F, PanZ X, Yao Y, Liu HL, Liu SR, Xie Z \& Li QF 2014 miR-34a targets the inhibin beta B gene, promoting granulosa cell apoptosis in the porcine ovary. Genetics and Molecular Research 13 2504-2512. (https://doi. org/10.4238/2014.January.14.6)

Tripurani SK, Lee KB, Wee G, Smith GW \& Yao J. 2011. MicroRNA-196a regulates bovine newborn ovary homeobox gene (NOBOX) expression during early embryogenesis. BMC Developmental Biology 1125. (https://doi.org/10.1186/1471-213X-11-25)

Tripurani SK, Wee G, Lee KB, Smith GW, Wang L, Jianboyao 2013 MicroRNA-212 post-transcriptionally regulates oocyte-specific basichelix-loop-helix transcription factor, factor in the germline alpha (FIGLA), during bovine early embryogenesis. PLOS ONE 17576114. (https://doi.org/10.1371/journal.pone.0076114)

van den Hurk R \& Zhao J 2005 Formation of mammalian oocytes and their growth, differentiation and maturation within ovarian follicles. Theriogenology 63 1717-1751. (https://doi.org/10.1016/j. theriogenology.2004.08.005)

Wang Y, Medvid R, Melton C, Jaenisch R \& Blelloch R 2007 DGCR8 is essential for microRNA biogenesis and silencing of embryonic stem cell self-renewal. Nature Genetics 39 380-385. (https://doi.org/10.1038/ ng1969)

Wang L, Li C, Li R, Deng Y, Tan Y, Tong C \& Qi H 2016 MicroRNA-764$3 p$ regulates $17 \beta$-estradiol synthesis of mouse ovarian granulosa cells by targeting steroidogenic factor-1. In Vitro Cellular and Developmental Biology: Animal 52 365-373. (https://doi.org/10.1007/s11626-0159977-9)

Wang Y, Xu C, Wang Y \& Zhang X 2017 MicroRNA-365 inhibits ovarian cancer progression by targeting Wnt5a. American Journal of Cancer Research 7 1096-1106.

Wei J, Zhang L, Li J, Zhu S, Tai M, Mason CW, Chapman JA, Reynolds EA, Weiner CP \& Zhou HH 2017 MicroRNA-205 promotes cell invasion by repressing TCF21 in human ovarian cancer. Journal of Ovarian Research 10 33. (https://doi.org/10.1186/s13048-017-0328-1) 
Wightman B, Ha I \& Ruvkun G 1993 Posttranscriptional regulation of the heterochronic gene lin-14 by lin-4 mediates temporal pattern formation in C. elegans. Cell 75 855-862. (https://doi.org/10.1016/00928674(93)90530-4)

Wilczynska A, Git A, Argasinska J, Belloc E \& Standart N 2016 CPEB and miR-15/16 co-regulate translation of cyclin E1 mRNA during xenopus oocyte maturation. PLoS ONE 11 e0146792. (https://doi.org/10.1371/ journal.pone.0146792)

Wright EC, Hale BJ, Yang C-X, Njoka JG \& Ross JW 2016 MicroRNA-21 and PDCD4 expression during in vitro oocyte maturation in pigs. Reproductive Biology and Endocrinology 14 21. (https://doi.org/10.1186/ s12958-016-0152-2)

Wu S, Sun H, Zhang Q, Jiang Y, Fang T, Cui I, Yan G \& Hu Y 2015 MicroRNA-132 promotes estradiol synthesis in ovarian granulosa cells via translational repression of Nurr1. Reproductive Biology and Endocrinology 13 94. (https://doi.org/10.1186/s12958-015-0095-z)

Xiang Y, Song Y, Li Y, Zhao D, Ma L \& Tan L 2016 miR-483 is down-regulated in polycystic ovarian syndrome and inhibits kgn cell proliferation via Targeting Insulin-Like Growth Factor 1 (IGF1). Medical Science Monitor International Medical Journal of Experimental and Clinical Research 22 3383-3393. (https://doi.org/10.12659/msm.897301)

Xiao G, Xia C, Yang J, Liu J, Du H, Kang X, Lin Y, Guan R, Yan P \& Tang S 2014 MiR-133b regulates the expression of the Actin protein TAGLN2 during oocyte growth and maturation: a potential target for infertility therapy. PLOS ONE 9 e100751. (https://doi.org/10.1371/journal. pone.0100751)

Xiong F, Hu L, Zhang Y, Xiao X \& Xiao J 2016a miR-22 inhibits mouse ovarian granulosa cell apoptosis by targeting SIRT1. Biology Open 5 367-371. (https://doi.org/10.1242/bio.016907)

Xiong XR, Lan DL, Li J, Zi XD \& Li MY 2016b Identification of candidate miRNAs and expression profile of yak oocytes before and after in vitro maturation by high-throughput sequencing. Reproduction in Domestic Animals 51 886-894. (https://doi.org/10.1111/rda.12754)

Xiong W, Lin Y, Xu L, Tamadon A, Zou S, Tian F, Shao R, Li X \& Feng Y 2017 Circulatory microRNA 23a and microRNA 23b and polycystic ovary syndrome (PCOS): the effects of body mass index and sex hormones in an Eastern Han Chinese population. Journal of Ovarian Research 1010 (https://doi.org/10.1186/s13048-016-0298-8)

Xu B, Hua J, Zhang Y, Jiang X, Zhang H, Ma T, Zheng W, Sun R, Shen W, Sha J et al. 2011a Proliferating cell nuclear antigen (PCNA) regulates primordial follicle assembly by promoting apoptosis of oocytes in fetal and neonatal mouse ovaries. PLOS ONE 6 e16046. (https://doi. org/10.1371/journal.pone.0016046)

Xu S, Linher-Melville K, Yang BB, Wu D \& Li J 2011b Micro-RNA378 (miR-378) regulates ovarian estradiol production by targeting aromatase. Endocrinology 152 3941-3951. (https://doi.org/10.1210/en.2011-1147)

Xu Y-W, Wang B, Ding C-H, Li T, Gu F \& Zhou C 2011c Differentially expressed micoRNAs in human oocytes. Journal of Assisted Reproduction and Genetics 28 559-566. (https://doi.org/10.1007/s10815-011-9590-0)

Yan G, Zhang L, Fang T, Zhang Q, Wu S, Jiang Y, Sun H \& Hu Y 2012 MicroRNA-145 suppresses mouse granulosa cell proliferation by targeting activin receptor IB. FEBS Letters 586 3263-3270. (https://doi. org/10.1016/j.febslet.2012.06.048)

Yang X, Zhou Y, Peng S, Wu L, Lin H-Y, Wang S \& Wang H 2012 Differentially expressed plasma microRNAs in premature ovarian failure patients and the potential regulatory function of mir-23a in granulosa cell apoptosis. Reproduction 144 235-244. (https://doi.org/10.1530/ REP-11-0371)

Yang S, Wang S, Luo A, Ding T, Lai Z, Shen W, Ma X, Cao C, Shi L, Jiang J et al. 2013 Expression patterns and regulatory functions of microRNAs during the initiation of primordial follicle development in the neonatal mouse ovary. Biology of Reproduction 89 126. (https://doi.org/10.1095/ biolreprod.113.107730)

Yao G, Yin M, Lian J, Tian H, Liu L, Li X \& Sun F 2010a MicroRNA-224 is involved in transforming growth factor-beta-mediated mouse granulosa cell proliferation and granulosa cell function by targeting Smad4. Molecular Endocrinology 24 540-551. (https://doi.org/10.1210/ me.2009-0432)

Yao N, Yang B-Q, Liu Y, Tan X-Y, Lu C-L, Yuan X-H \& Ma X 2010b Follicle-stimulating hormone regulation of microRNA expression on progesterone production in cultured rat granulosa cells. Endocrine $\mathbf{3 8}$ 158-166. (https://doi.org/10.1007/s12020-010-9345-1)

Ye Z, Le Zhao, Li J, Chen W \& Li X 2015 miR-30d blocked transforming growth factor beta1-induced epithelial-mesenchymal transition by targeting snail in ovarian cancer cells. International Journal of Gynecological Cancer Official Journal of the International Gynecological Cancer Society 25 1574-1581. (https://doi.org/10.1097/ IGC.0000000000000546)

Yi R, Qin Y, Macara IG \& Cullen BR 2003 Exportin-5 mediates the nuclear export of pre-microRNAs and short hairpin RNAs. Genes and Development 17 3011-3016. (https://doi.org/10.1101/gad.1158803)

Yin M, Lü M, Yao G, Tian H, Lian J, Liu L, Liang M, Wang Y \& Sun F 2012 Transactivation of microRNA-383 by steroidogenic factor-1 promotes estradiol release from mouse ovarian granulosa cells by targeting RBMS1. Molecular Endocrinology 26 1129-1143. (https://doi.org/10.1210/ me.2011-1341)

Yin M, Wang X, Yao G, Lu M, Liang M, Sun Y \& Sun F 2014 Transactivation of micrornA-320 by microRNA-383 regulates granulosa cell functions by targeting E2F1 and SF-1 proteins. Journal of Biological Chemistry 289 18239-18257. (https://doi.org/10.1074/jbc.M113.546044)

Yu C, Li M, Wang Y, Liu Y, Yan C, Pan J, Liu J \& Cui S 2016 miR-375 mediates $\mathrm{CRH}$ signaling pathway in inhibiting E2 synthesis in porcine ovary. Reproduction 153 63-73. (https://doi.org/10.1530/REP-16-0323)

Zhang J, Ji X, Zhou D, Li Y, Lin J, Liu J, Luo H \& Cui S 2013a miR-143 is critical for the formation of primordial follicles in mice. Frontiers in Bioscience 18 588-597. (https://doi.org/10.2741/4122)

Zhang Q, Sun H, Jiang Y, Ding L, Wu S, Fang T, Yan G \& Hu Y 2013b MicroRNA-181a suppresses mouse granulosa cell proliferation by targeting activin receptor IIA. PLOS ONE 8 e59667. (https://doi. org/10.1371/journal.pone.0059667)

Zhang X-D, Zhang Y-H, Ling Y-H, Liu Y, Cao H-G, Yin Z-J, Ding J-P \& Zhang X-R 2013c Characterization and differential expression of microRNAs in the ovaries of pregnant and non-pregnant goats (Capra hircus). BMC Genomics 14 157. (https://doi.org/10.1186/1471-216414-157)

Zhang H, Jiang X, Zhang Y, Xu B, Hua J, Ma T, Zheng W, Sun R, Shen W, Cooke HJ et al. 2014 microRNA 376a regulates follicle assembly by targeting Pcna in fetal and neonatal mouse ovaries. Reproduction 148 43-54. (https://doi.org/10.1530/REP-13-0508)

Zhang L, Zhang XX, Zhang X, Lu Y, Li L \& Cui S 2017 MiRNA-143 mediates the proliferative signaling pathway of $\mathrm{FSH}$ and regulates estradiol production. Journal of Endocrinology 234 1-14. (https://doi. org/10.1530/JOE-16-0488)

Zhou J, Lei B, Li H, Zhu L, Wang L, Tao H, Mei S \& Li F 2017 MicroRNA-144 is regulated by CP2 and decreases COX-2 expression and PGE2 production in mouse ovarian granulosa cells. Cell Death \& Disease $\mathbf{8}$ e2597. (https://doi.og/10.1038/cddis.2017.24)

Zi X-D, Lu J-Y \& Ma L 2017 Identification and comparative analysis of the ovarian microRNAs of prolific and non-prolific goats during the follicular phase using high-throughput sequencing. Scientific Reports 7 1921. (https://doi.org/10.1038/s41598-017-02225-x)

Received 14 July 2017

First decision 14 September 2017

Revised manuscript received 26 October 2017

Accepted 23 November 2017 